\title{
Two Hopeless Causes: Education and Incarceration
}

\author{
Dr. Charles E. Notar (Emeritus) \\ Jacksonville State University
}

\begin{abstract}
There are a myriad study providing cost figures for education and prisons in the United States. Most have in the American prison system an estimated 2.2 million inmates and with an estimated cost of $\$ \mathbf{8 0}$ billion that eclipses the GDP of 133 nations. That's on average $\$ 36,000$ per prisoners per year. Current expenditures for public elementary and secondary schools are projected to be $\$ 623.5$ billion for the 2017-18 school year. The current expenditure per student is projected to be $\$ 12,300$ for the $2017-18$ school year. The article purports that the financing policies of education and incarceration are not providing the results intended.
\end{abstract}

Key words: Education costs, costs of incarceration/imprisonment, population in prisons incarceration/imprisonment, student in education, student costs, total money spent/education/students/incarceration/imprisonment/prisons

\section{INTRODUCTION}

Two hopeless causes seemed to be an apt title for this article. On the one hand we have the teacher featured in TIME (09/24/2018) cover stating the following "I have a master's degree, 16 years of experience, work two extra jobs and donate blood plasma to pay the bills. I'm a teacher in America (emphasis added). On the other hand we have a new study examining the economic toll of mass incarceration in the United States concludes that the full cost exceeds \$1 trillion - with about half of that burden falling on the families, children and communities of people who have been locked up (3).

While the above quote from TIME is a headliner two interesting comments have been made many years ago that the authors believe show the frustration they felt when they started researching this paper:

Victor Hugo's 19th century remark, "He who opens a school door closes a prison," still holds true today (19).

While the old saying notes that crime doesn't pay, that doesn't hold true for America's system of incarceration, which has seen spending more than triple since 1980 (36).

This is not a new problem as we see from Steven Hawkins (2010) in his article Education vs. Incarceration states "More money must go to schools than to prisons before high-crime neighborhoods can truly be reformed." (para 1).

Teacher have high demands place on them. They are not paid for the work they do. There are 3.2 million teachers full-time in public school's kindergarten through high school. While teacher want higher salaries, benefits and funding for public education decades long and bipartisan war on public education, born of frustration with teachers' unions, a desire to standardize curricula and a professed commitment to fiscal austerity. (TIME, 28). Ipsos/USA Today $(09 / 12 / 2018)$ says of those surveyed nearly $60 \%$ think teachers are underpaid (TIME, 29). Nationwide estimated aver public school salary is $\$ 58,950$ according to the National Center for Educational Statistics (TIME, 30). 
On the other side of the problem is the nationwide numbers of nearly 2.4 million people behind bars, even though over the last 20 years the crime rate has actually dropped by more than $40 \%$. "The United States has about 5 percent of the world's population, but we have $25 \%$ of the world's prisoners - we incarcerate a greater percentage of our population than any country on Earth," said Michael Jacobson, director of the non-partisan Vera Institute of Justice. He also ran New York City's jail and probation systems in the 1990s (5).

Over the last year and most recently, there has been great concerns and energies placed on failing public schools in America. Experts from across the country are sharing their insights and providing much needed dialogue. However, there is an important piece of the conversation that's being sugar coated now and in the past by many education, political and community leaders, especially since the war on drugs started in 1969 (8).

Where possible the latest data is used in this paper, however, the use of earlier data was necessary because some information on the 2018-19 school/incarceration year is not available. This paper presents selected highlights from prior years to provide some context for the current school years (47).

\section{THE COST OF INCARCERATION}

The cost of incarceration is hard to put your finger on. One thing is certain ... it is huge. A report by the organization, "The Price of Prisons," states that the cost of incarcerating one inmate in Fiscal 2010 was $\$ 31,307$ per year. "In states like Connecticut, Washington state, New York, it's anywhere from $\$ 50,000$ to $\$ 60,000$," he said. Yes - $\$ 60,000$ a year. That's a teacher's salary, or a firefighter's (2). Yes - $\$ 60,000$ a year. That's a teacher's salary, or a firefighter's. A firefighter according to (71) ranges from $\$ 42,206-62,238$. The Bureau of Labor Statistics (72, Figure 1) shows a range of $\$ 24,490-83,570$. The ranges are across states and did not show if the salaries include the requirement of also being para-medic qualified which a majority of cities now require of their firefighters.

\begin{tabular}{|c|c|c|c|c|}
\hline $\begin{array}{c}\text { Employment } \\
(1)\end{array}$ & $\begin{array}{c}\text { Employment } \\
\text { RSE }(3)\end{array}$ & $\begin{array}{c}\text { Mean } \\
\text { hourly } \\
\text { wage }\end{array}$ & $\begin{array}{c}\text { Mean } \\
\text { annual } \\
\text { wage }(2)\end{array}$ & $\begin{array}{c}\text { Wage RSE } \\
(3)\end{array}$ \\
\hline 319,860 & $0.7 \%$ & $\$ 24.97$ & $\$ 51,930$ & $0.8 \%$ \\
\hline
\end{tabular}

Percentile wage estimates for this occupation:

\begin{tabular}{|c|c|c|c|c|c|}
\hline Percentile & $\mathbf{1 0 \%}$ & $\mathbf{2 5 \%}$ & $\begin{array}{c}\mathbf{5 0 \%} \\
\text { (Median) }\end{array}$ & $\mathbf{7 5 \%}$ & $\mathbf{9 0 \%}$ \\
\hline $\begin{array}{c}\text { Hourly } \\
\text { Wage }\end{array}$ & $\$ 11.77$ & $\$ 16.06$ & $\$ 23.60$ & $\$ 32.03$ & $\$ 40.18$ \\
\hline $\begin{array}{c}\text { Annual } \\
\text { Wage (2) }\end{array}$ & $\$ 24,490$ & $\$ 33,400$ & $\$ 49,080$ & $\$ 66,610$ & $\$ 83,570$ \\
\hline
\end{tabular}

Figure 1: The Bureau of Labor Statistics Firefighter Wages $(68,73)$

While this section of the article provided a set of costs for incarceration there are several other sites that have tried to tie down actual costs. The following are a few examples.

Our epidemic of incarceration costs us taxpayers $\$ 63.4$ billion a year (5). "The United States spends about $\$ 80$ billion a year on incarceration" (25). Another report from The Hamilton Project, which is part of Washington, D.C., think tank The Brookings Institution places the country's annual $\$ 80$ billion price tag for incarceration. 
While the amounts other studies have broken down the costs of incarceration by state, type of incarceration. Since 2015, California's per-inmate costs have surged nearly $\$ 10,000$, or about $13 \%$. New York is a distant second in overall costs at about $\$ 69,000$ (7).

The fee to cover the average cost of incarceration for Federal inmates in Fiscal Year 2015 was $\$ 31,977.65$ (\$87.61 per day). (Please note: There were 365 days in FY 2015.) The average annual cost to confine an inmate in a Residential Re-entry Center for Fiscal Year 2015 was $\$ 26,082.90$ (\$71.46 per day) (9).

It cost tax payers $\$ 26,094$ to house a prisoner for a year, and the Bureau of Prisons now spends close to $\$ 6.4$ billion in public money annually, the report said (McCormack, 2013 as cited in 12).

While the amounts other studies have broken down the costs of incarceration by state, type of incarceration. The average cost of incarcerating an American prisoner varies from state to state. Some states, like Indiana have managed to keep prices low at around $\$ 14,000$ per inmate. While states like New York pay around $\$ 60,000$ to keep its citizens behind bars. The costs of running the American prison system is expensive and has become increasingly so despite public opposition (6).

Seeing these figures, you may ask "Where is all of this money going?" While the list is not exhaustive here are a few of the direct costs of incarceration: as employee benefits and taxes, pension contributions, retiree health care contributions, legal judgments and claims are deemed central administrative costs. Inmate costs include hospital care, education and training and outside of their corrections departments.

Ancillary costs include more pre-trial time will be needed to prepare: cases typically take a year to come to trial

2. more pre-trial motions will be filed and answered

3. more experts will be hired

4. Twice as many attorneys will be appointed for the defense, and a comparable team for the prosecution

5. jurors will have to be individually quizzed on their views about the death penalty, and they are more likely to be sequestered

6. two trials instead of one will be conducted: one for guilt and one for punishment

7. the trial will be longer: a cost study at Duke University estimated that death penalty trials take 3 to 5 times longer than typical murder trials [list is not all inclusive] (6).

The authors stated earlier "Teacher have high demands place on them. They are not paid for the work they do. We can replace one word in that sentence ... teacher for counselors, prison guards and medical providers.

\section{PEOPLE INCARCERATED IN U.S.}

America has one of the world's most bloated prison systems, with federal prison costs (Bureau of Prisons) that eat up a third of the Justice Department's budget (11). The authors state this because the following examples are sharing the other $3 / 2$ of the budget: Bureau of Alcohol, Tobacco, Firearms and Explosives, Civil Rights Division, Office of the Attorney General, Federal Bureau of Investigation (FBI), U.S. Attorneys, U.S. Marshal's Office [(52 departments in the Justice Department] $(75,76)$. 
Nearly $75 \%$ of imprisonment spending happens at the state level, where dollars are drawn from a general fund that is meant to pay for a range of public needs, including health care, housing, public assistance, and education (1).

Spending money on prisons is a particularly poor investment relative to spending money on education. Some urban neighborhoods have seen large swaths of their population relocated to prisons in the past several decades. These so-called million-dollar blocks - where taxpayers have spent a million dollars or more keeping former neighborhood residents locked up in prison - can be desolate places, full of "children who are missing their parents, households that are missing their breadwinners, [and] families who must support returning offenders who are now much harder to employ," as my colleague Emily Badger wrote last year. And as families in these neighborhoods are hollowed out by aggressive incarceration policies, children have an even harder time escaping their circumstances, creating a vicious cycle (Ingraham, 2016 as cited in 21).

How many people are actually locked up in the United States? Well, as it turns out, it's hard to say. Inconsistent and fragmentary data has made piecing together the "whole pie" of U.S. federal, state, local and other types of confinement data difficult (Figure 2). Lucky for us, the Prison Policy Initiative has released a comprehensive graphic that aggregates the available information and helps to explain the complicated and expansive U.S. correctional system (33).

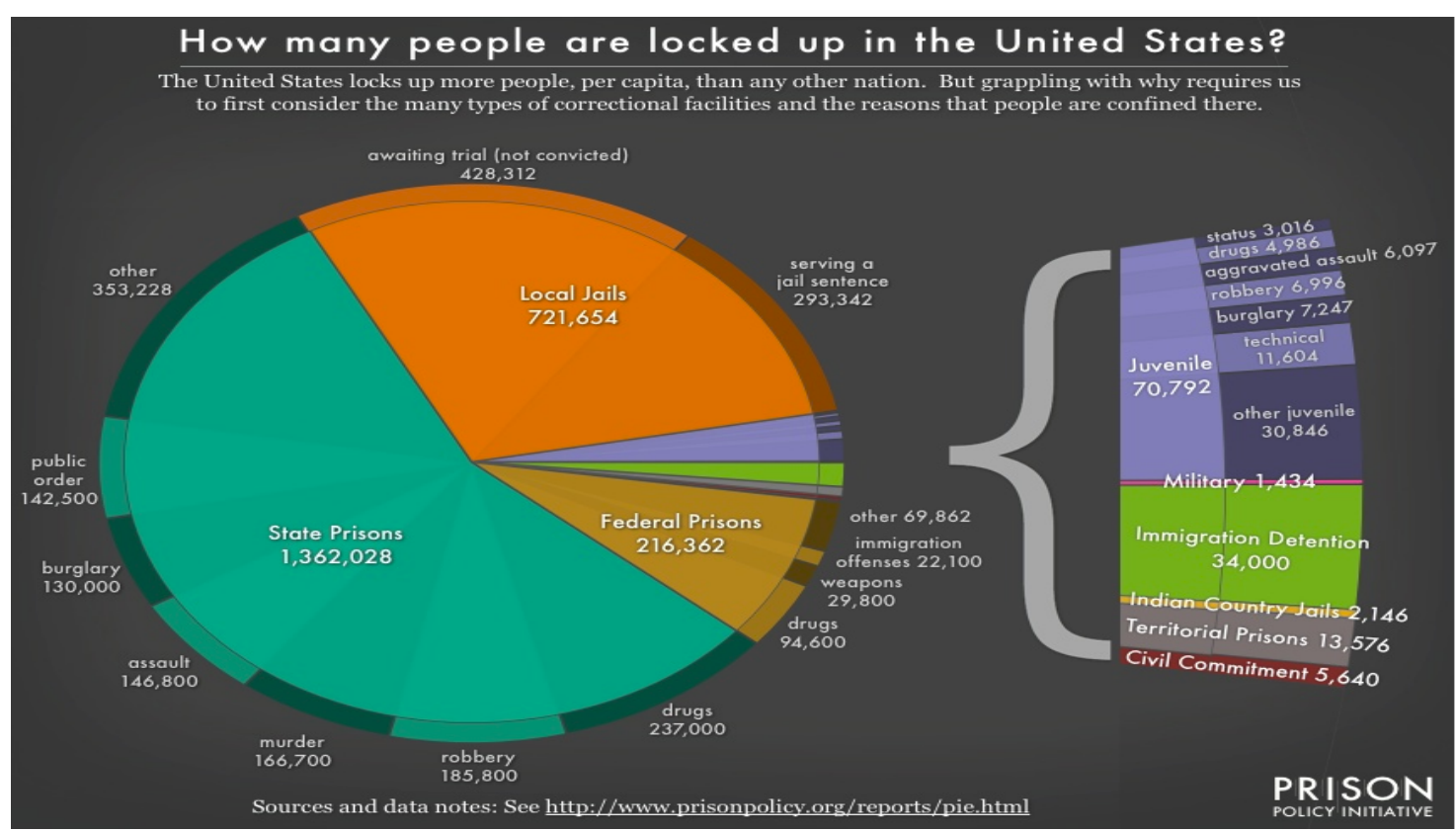

Figure 2: How Many People locked up in the United States (33)

From the collected data, the Initiative found that the incarceration system in this country "hold[s] more than 2.4 million people in 1,719 state prisons, 102 federal prisons, 2,259 juvenile correctional facilities, 3,283 local jails, and 79 Indian Country jails as well as in military prisons, immigration detention facilities, civil commitment centers, and prisons in the U.S. territories."[1] This total distinguishes the United States with the highest incarcerated population in the world (33).

Of course, not all of those people stay in prison. Annually, 688,000 people are released from state and federal prisons back into society. This number adds to the almost 12 million people who cycle through local jails each year, revealing an "enormous jail churn."[2] As the above graphic indicated, a contributing factor to this massive and steady churn in jails is the nearly 
430,000 people who at any given moment are occupying local cells awaiting trial and conviction. The rest are being held for minor offenses with sentences under a year. (Note: While probationers and parolees might also be included in the jail churn, it is important to note that this data excludes probation/parole figures (33).

Regardless of what figures are used to determine the cost of incarceration the CCA, Vera Institute of Justice, The Nation, AFSC, CJR, University of Chicago Crime Lab, Barclays Capital, NPR, AFSC state the American prison system is massive that its estimated turnover of $\mathbf{\$ 7 4}$ billion eclipses the GDP of 133 nations [Emphasis added) (77).

\section{Death Penalty}

\section{DEATH PENALTY AND LIFE IMPRISONMENT}

While researching the authors noted a number of interesting details that are subsumed in aggregate numbers and in most instances state individual numbers. The first is the weight of the death penalty on cost of incarceration. A few definitions for clarity of article should be provided.

Capital punishment refers to the process of sentencing convicted offenders to death for the most serious crimes (capital crimes) and carrying out that sentence. The specific offenses and circumstances which determine if a crime (usually murder) is eligible for a death sentence are defined by statute and are prescribed by Congress or any state legislature (78).

Death row refers to incarcerated persons who have been sentenced to death and are awaiting execution (as in "inmates on death row"). Historically, death row was a slang term which referred to the area of a prison in which prisoners who were under a sentence of death were housed. Usage of the term continues despite the fact that many states do not maintain a separate unit or facility for condemned inmates (78).

Life imprisonment refers to a sentence of incarceration for a lengthy time. In some states' 'life' may mean 'whole life.' Mostly there are provisions for a minimum term or for parole or for pardon or some combination (80). Shafer v. S.C., 532 U.S. 36, 56-57 (U.S. 2001, as cited in 55) is more blunt referring to life imprisonment as "incarceration of the defendant until his death". The defendant is imprisoned in the state penitentiary for the balance of his natural life (80).

While ethical and legal objections are the most common reasons critics oppose the death penalty, the cost of capital punishment is growing as a reason some are citing to oppose the method of punishment (79). While researching the authors noted a number of interesting details that are subsumed in aggregate numbers and in most instances state individual numbers. The first is the weight of the death penalty on cost of incarceration. The death penalty is more expensive, mostly because of the upfront costs of the legal process (before and during the initial trial) (6).

Richard C. Dieter (1999) of the Death Penalty Information Center states "The study counted death penalty case costs through to execution and found that the median death penalty case costs $\$ 1.26$ million. Non-death penalty cases were counted through to the end of incarceration and were found to have a median cost of $\$ 740,000$. The costs of the death penalty begin to accumulate from the very beginning of a death penalty case (62). Kelly Phillips Erb (2014) in a Forbes article cites the same study Fox reported that studies have "uniformly and conservatively shown that a death-penalty trial costs $\$ 1$ million more than one in which prosecutors seek life without parole." (Para 10,51) 
It is a commonly held belief that the death penalty is a cheaper and more cost-effective way to deal with the most dangerous criminals in the United States. The totals for a government funded execution from trial to capital punishment and the incarceration of an inmate for life. That may not, however, be true. "It's 10 times more expensive to kill them than to keep them alive, "says Donald McCartin, known as The Hanging Judge of Orange County in California (81). Discussion must be made between the actual cost of execution and the cost of execution before the actual event ... the cost between the actual execution and the cost of keeping an inmate in prison: those aren't apples to apples comparisons.

The actual execution costs taxpayers fairly little. Most states remain mum on the cost of lethal injections because of privacy concerns from pharmaceutical companies, it's estimated that the drugs run about $\$ 100$. While the actual execution costs taxpayers fairly little (the drugs used in Texas run a mere \$83), the costs associated with death penalty trials and the resulting incarceration are disproportionately higher (82).

\section{Life in Prison}

The costs for a non-death penalty murder case is $\$ 1.1$ million $(\$ 870,000$ in imprisonment, $\$ 250,000$ in trial), while the costs for a death penalty case are $\$ 3$ million $(\$ 1.3$ million in imprisonment, \$1.7 million in trial (83).

A 2014 study out of Kansas reported that a death row prisoner costs $\$ 49,380$ to house per year, whereas a general population prisoner costs $\$ 24,690$. As appeals come to take longer and challenges to lethal injection protocols slow down the execution process, these housing costs add up (84)

A recent Duke University study of North Carolina's death penalty costs found that the state could save $\$ 11$ million a year by substituting life in prison for the death penalty. An earlier Duke study found that the state spent $\$ 2.1$ million more on a death penalty case (52).

Capital punishment is currently authorized in 31 states, by the federal government and the U.S. military (85). As of 2011, only seventeen states have abolished the death penalty. They are Alaska, Connecticut, Hawaii, Illinois, Iowa, Maine, Maryland, Massachusetts, Michigan, Minnesota, New Jersey, New Mexico, New York, North Dakota, Rhode Island, Vermont, West Virginia and Wisconsin.

When jurors opt for life without parole-known in the justice system as LWOP-rather than the death penalty for convicted defendants, there are financial consequences for taxpayers.

According to statistics provided by the office of California's nonpartisan Legislative Analyst, the current annual cost for maintaining an inmate in a state prison is $\$ 47,102$. The Department of Corrections and Rehabilitation, however, places the number at $\$ 44,563$ (68).

Jonathan C. Holeman and Samuel C. Wright, both convicted recently in a nine-year-old Lake Arrowhead double murder, are both 31 years of age. Using the Legislative Analyst's numbers, if both were sentenced to life without parole and lived to the age of 65 , the 34-year cost of housing, feeding and keeping them secure would amount to $\$ 1.598$ million apiece, without factoring in the effects of inflation (68).

But $\$ 1,612$ a year might be eliminated from the annual cost, assuming prisoners who could never be paroled are not enrolled in rehabilitation programs. 
However, at an annual cost of $\$ 137,102$, a prisoner who sits on death row for 20 years could cost taxpayers a total of $\$ 2,742,040$ in that time 68 ).

And, while all of this waiting is going on, the process has not ground to a halt. Quite the opposite, in fact. The appeals process consumes hours of labor, not only by court staff, but also by the often court-appointed, tax payer funded, and constitutionally guaranteed public defenders. As a result, some estimate that it costs U.S. taxpayers between $\$ 50$ and $\$ 90$ million dollars more per year (depending on the jurisdiction) to prosecute death penalty cases than life sentences 68).

Consequently, while cost is not the only factor to be considered, when it comes down to an argument regarding the benefits of the death penalty to society, the argument that it is cheaper to execute someone than keep them alive in prison for the rest of their lives is utterly wrong 68).

The death penalty is more expensive, mostly because of the upfront costs of the legal process (before and during the initial trial). It is supposed to prevent executions of innocent people. Here is an excerpt of an official state report (Findings in other states are similar): "The study counted death penalty case costs through to execution and found that the median death penalty case costs $\$ 1.26$ million. Non-death penalty cases were counted through to the end of incarceration and were found to have a median cost of $\$ 740,000$. For death penalty cases, the pre-trial and trial level expenses were the most expensive part, $49 \%$ of the total cost. The investigation costs for death-sentence cases were about 3 times greater than for non-death cases. The trial costs for death cases were about 16 times greater than for non-death cases ( $\$ 508,000$ for death case; $\$ 32,000$ for non-death case)." (. Kansas: Performance Audit Report: Costs Incurred for Death Penalty Cases: A K-GOAL Audit of the Department of Corrections) (67).

Why is the death penalty so expensive? The costs of the death penalty begin to accumulate from the very beginning of a death penalty case. Here are just a few of the contributing factors:

8. more pre-trial time will be needed to prepare: cases typically take a year to come to trial

9. more pre-trial motions will be filed and answered

10. more experts will be hired

11. twice as many attorneys will be appointed for the defense, and a comparable team for the prosecution

12. jurors will have to be individually quizzed on their views about the death penalty, and they are more likely to be sequestered

13. two trials instead of one will be conducted: one for guilt and one for punishment

14. the trial will be longer: a cost study at Duke University estimated that death penalty trials take 3 to 5 times longer than typical murder trials

Many people are surprised to find this out, including several who answered your question. I hope they will look at sources (66).

Death in prison is a sentence that saves money. The death penalty is significantly more expensive than condemning a person to die in prison. Simply housing prisoners on death row costs California tax payers an additional $\$ 90,000$ per prisoner per year, above what it would cost to house them with the general prison population, which adds up to $\$ 59$ million a year. The price tag for California's new death row is $\$ 336$ million. All of those costs would be avoided if the people on death row were sentenced to die in prison and moved to the general population. 
Viewed another way, we spent $\$ 250$ million to carry out the sentences of the 11 prisoners executed between 1977 and 2002, money that could have been spent on other public safety programs, if those prisoners had been sentenced to die in prison instead of executed (65).

The death penalty costs more, delivers less, and puts innocent lives at risk. Life without parole provides swift, severe, and certain punishment. It provides justice to survivors of murder victims and allows more resources to be invested into solving other murders and preventing violence. Sentencing people to die in prison is the sensible alternative for public safety and murder victims' families (65).

After decades of moral arguments reaching biblical proportions, after long, twisted journeys to the nation's highest court and back, the death penalty may be abandoned by several states for a reason having nothing to do with right or wrong: Money (64). Turns out, it is cheaper to imprison killers for life than to execute them, according to a series of recent surveys. Tens of millions of dollars cheaper, politicians are learning, during a tumbling recession when nearly every state faced job cuts and massive deficits (64). An increasing number of them are considering abolishing capital punishment in favor of life imprisonment, not on principle but out of financial necessity (64).

"It's 10 times more expensive to kill them than to keep them alive," though most Americans believe the opposite, said Donald McCartin, a former California jurist known as "The Hanging Judge of Orange County" for sending nine men to death row (64). Deep into retirement, he lost his faith in an eye for an eye and now speaks against it. What changed a mind so set on the ultimate punishment? (64).

An example of a waste of time and money is California's legendarily slow appeals system, which produces an average wait of nearly 20 years from conviction to fatal injection - the longest in the nation. Of the nine convicted killers McCartin sent to death row, only one has died. Not by execution, but from a heart attack in custody (64).

\section{INCARCERATION OF ILLEGAL ALIENS}

The second interesting aspect lost in aggregate numbers is the number of aliens/illegals in our prisons. The prisoners involved in this section are here as foreign national who have come into the United States, committed a crime, been captured, and imprisoned or are being held for crossing the border illegally (Mora, 2010 as cited in 43).

More than 11,000 gang members and their associates have been arrested over a three-year period thanks to a crackdown in immigration enforcement by the U.S. Immigration and Customs Enforcement. (Mora, 2010 as cited in 43).

(CNSNews.com) - U.S. taxpayers are spending at least $\$ 18.6$ million per day to house an estimated 300,000 to 450,000 illegal immigrants who are incarcerated and eligible for deportation from the United States, according to data from the Department of Homeland Security (DHS) and the Department of Justice (DOJ) (Mora, 2010 as cited in 43).

The cost per day for these prisoners is based on Justice Department incarceration cost estimates from 2001 and on the lower-end figure of 300,000 incarcerated deportable aliens, which means the actual expense today could be substantially higher than $\$ 18.6$ million per day (Mora, 2010 as cited in 43).

The prisoners involved here are foreign national who have come into the United States, committed a crime, been captured, and imprisoned (Mora, 2010 as cited in 43). 
The cost of $\$ 22,650$ per year to house just one inmate at the state level equals about $\$ 62$ a day ( $\$ 22,650$ divided by 365 days). In the Federal Bureau of Prisons, it also averages out to $\$ 62$ per day $(\$ 22,632$ divided by 365 days) (Mora, 2010 as cited in 43$)$.

The DOJ spokeswoman told CNSNews.com that, according to its latest figures, "In 2008 there were 785,556 inmates in the nation's [local and county] jails and 1,518,559 inmates in state and federal prisons." That equals 2,304,115 inmates in total in the United States (Mora, 2010 as cited in 43).

CNSNews.com reported U.S. taxpayers are spending at least $\$ 18.6$ million per day to house an estimated 300,000 to 450,000 illegal immigrants who are incarcerated and eligible for deportation from the United States, according to data from the Department of Homeland Security (DHS) and the Department of Justice (DOJ) (Mora, 2010 as cited in 43).

Given those numbers, 300,000-450,000 range 300,000 incarcerated criminal aliens would equal 13 percent of the entire inmate population of the United States, while 450,000 incarcerated criminal aliens would equal 19.5 percent of the entire inmate population (Mora, 2010 as cited in 43).

More than 11,000 gang members and their associates have been arrested over a three-year period thanks to a crackdown in immigration enforcement by the U.S. Immigration and Customs Enforcement. (Mora, 2010 as cited in 43). This is only one segment of illegals arrested for crimes.

The cost of $\$ 22,650$ per year to house just one inmate at the state level equals about $\$ 62$ a day $(\$ 22,650$ divided by 365 days). In the Federal Bureau of Prisons, it also averages out to $\$ 62$ per day (\$22,632 divided by 365 days) (Mora, 2010 as cited in 43$)$.

The other segment of illegals is those awaiting deportation. The cost per day for these prisoners is based on Justice Department incarceration cost estimates from 2001 and on the lower-end figure of 300,000 incarcerated deportable aliens, which means the actual expense today could be substantially higher than $\$ 18.6$ million per day (Mora, 2010 as cited in 43).

The cost per day for these prisoners is based on Justice Department incarceration cost estimates from 2001 and on the lower-end figure of 300,000 incarcerated deportable aliens, which means the actual expense today could be substantially higher than $\$ 18.6$ million per day (Mora, 2010 as cited in 43).

Mora (2010 as cited in 43) asserts the U.S. is spending at least \$18.6 million per day to incarcerate illegal aliens; More than 195,000 illegal aliens deported in fiscal 2010 had committed crimes here (Mora, 2010 as cited in 43).

The DOJ spokeswoman told CNSNews.com that, according to its latest figures, "In 2008 there were 785,556 inmates in the nation's [local and county] jails and 1,518,559 inmates in state and federal prisons." That equals 2,304,115 inmates in total in the United States (Mora, 2010 as cited in 43).

\section{COSTS BEYOND INCARCERATION FOR THEIR FAMILIES}

There are serious economic implications in incarceration beyond the actual costs (33). The cost of imprisonment isn't just levied against taxpayers and the horrors of mass incarceration don't stop and start at the prison gates (34). 
Yet, almost 2 million children in this country are growing up with a parent behind bars. And this scene plays out in visiting rooms in prisons and jails across the country on a daily basis. The children's parents may have committed a crime. But the children are also doing time. Their childhoods are marked by the loss of their parents. And this is a loss that that has unimaginable costs to these children and their communities - one that can't be calculated in dollars in cents (34).

But the money the United States spends on imprisonment certainly adds up. On average it costs taxpayers anywhere from $\$ 20,000$ to $\$ 30,000$ to imprison one person for a year. Multiply those annual costs by the millions of people who are currently behind bars in this country and the cost of imprisonment easily exceeds $\$ 60$ billion a year (34).

Every penny our government spends on prisons and jails is a penny that does not fund schools, health care, economic development, and transportation infrastructure.

That's why state legislatures should ensure that at sentencing judges have before them both the cost to taxpayers and the cost of imprisonment to families and communities-including those costs that are not easily quantifiable. Before sending someone away, lawmakers, prosecutors and judges should be forced to document and confront the devastating, farreaching human consequences of mass imprisonment (34).

There is no question that imprisonment imposes a significant financial burden on the families of those who are imprisoned. There is of course, the cost of staying connected to your loved one while they live behind bars (34).

There is also the cost of visitation. Prisons are generally located in rural areas far away from population centers - hundreds of miles from public transportation. Families and their advocates have cribbed together innovative solutions to this-ride sharing, bus rentals. But often families must save up for gas, hotel stays, take time off work and give up wages in order to maintain their connections with those behind bars (34).

\section{Introduction}

\section{LOCATION OF THOSE INCARCERATED}

Figures 3, 4, 5, show where those incarcerated are located and reasons for incarceration and racial mix of those in prison. Figure 6 is necessary due to the drop out rates shown about and the lack of educational attainment. Figure 4 shows the majority of those incarcerated are in state and local prisons/jails. This places a heavy burden on those budgets. As most teachers and administrators know, spending on education in the United States varies widely from state to state and even among individual school districts. Local and state taxes, federal allocations and special grants are just a few of the factors which affect the distribution of money among schools. Most public schools rely heavily on property taxes for financial support. But as housing values fell over the past decade, local governments needed to reassess property values, which led to significant budget shortfalls for education (26). 


\section{Total population of US prisons, 1990-2011}

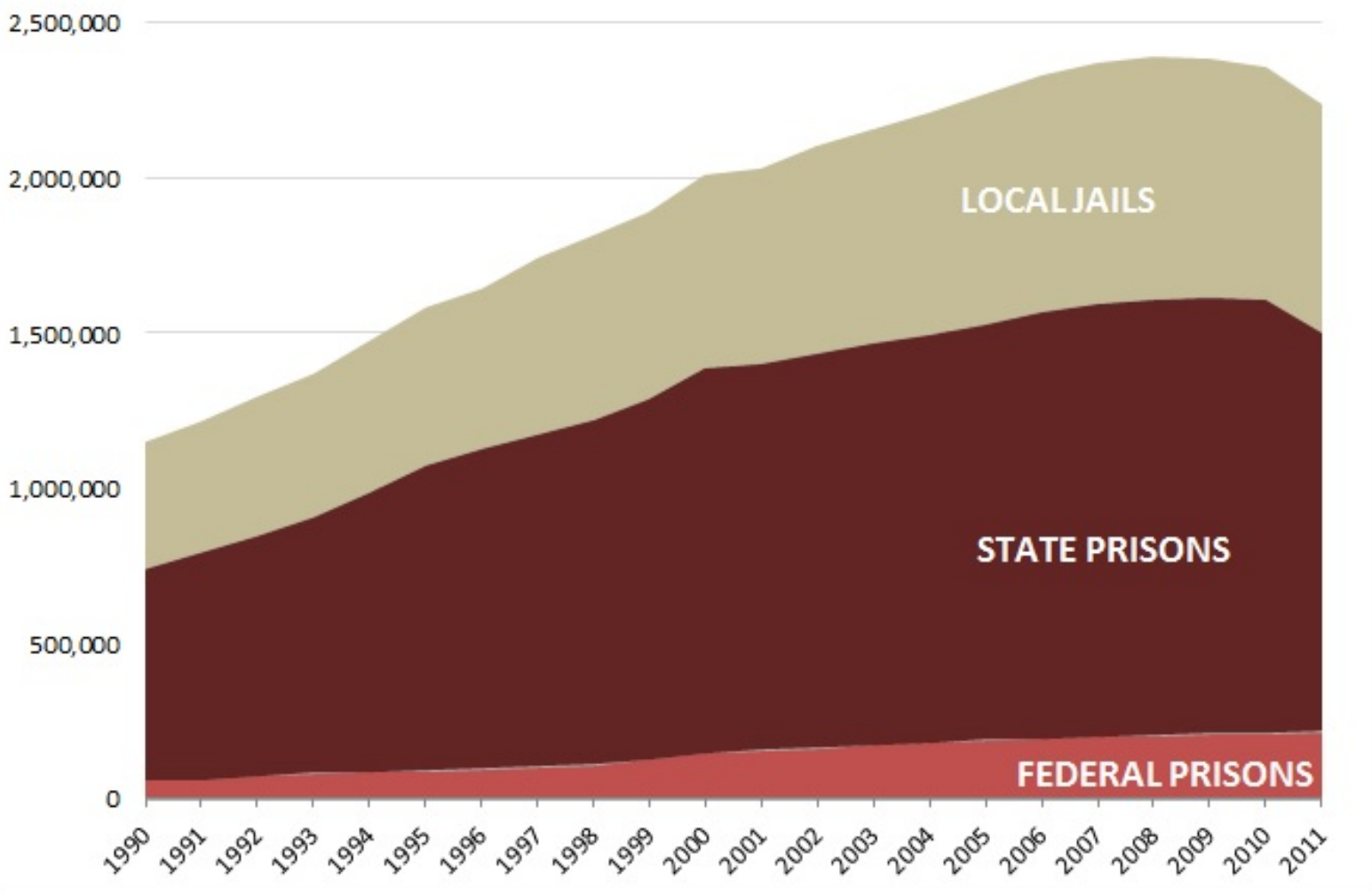

Figure 3: Total population of US prisons, 1990-2011 (Walden, 2013).

Figure 4 shows in aggregate terms the offenses the crimes committed that lead to where imprisoned. This figure is key to a number of problems that affect costs of education and imprisonment that will be discussed further in this article.

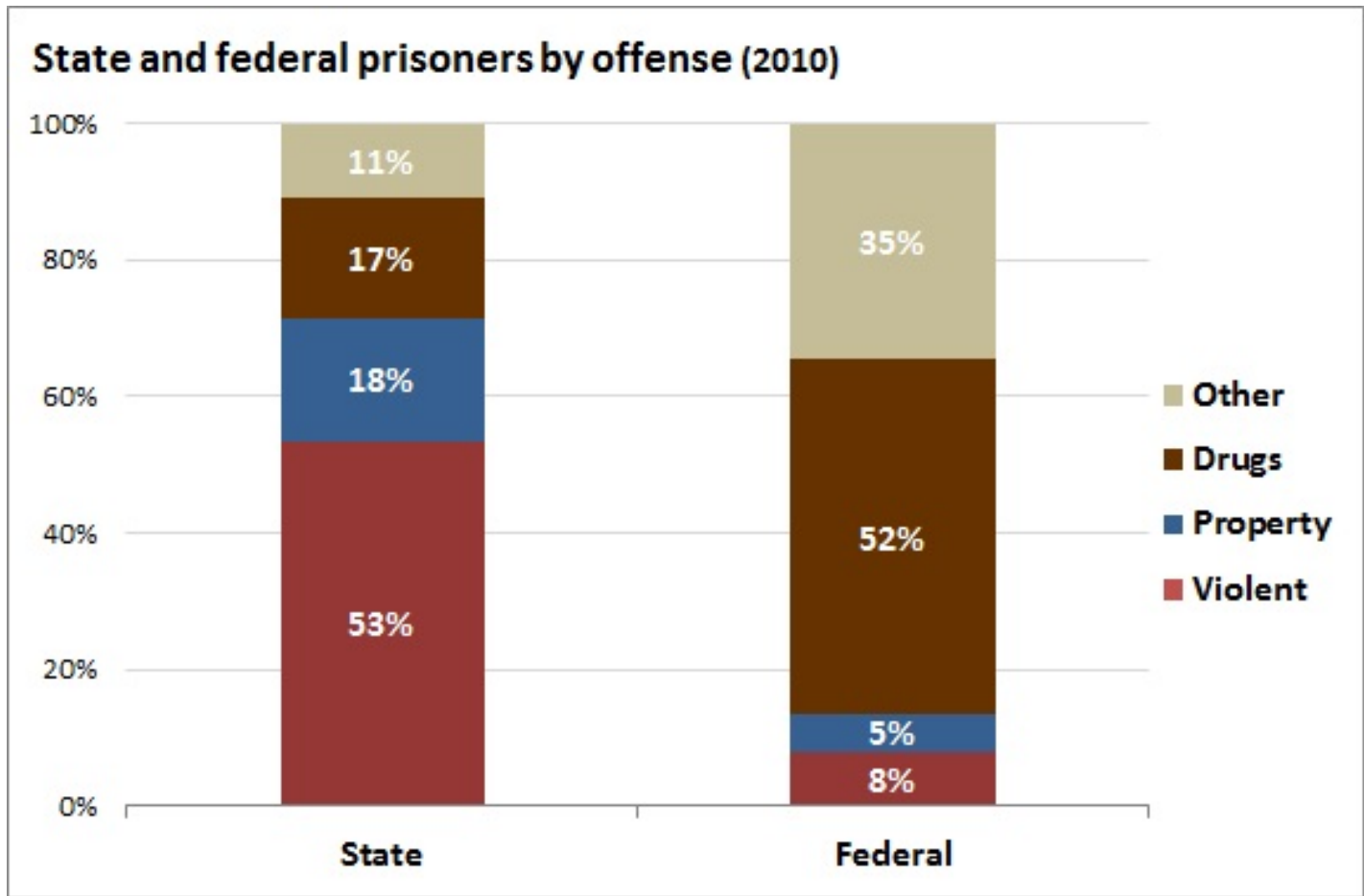

Figure 4: offenses committed that lead to federal and state imprisonment (Walden, 2013).

As commented on in figure 5 state and local imprisonment have a direct impact on local and state budgets. Similarly, the offenses are impacted by the racial mix in the prison population (figure 5). 


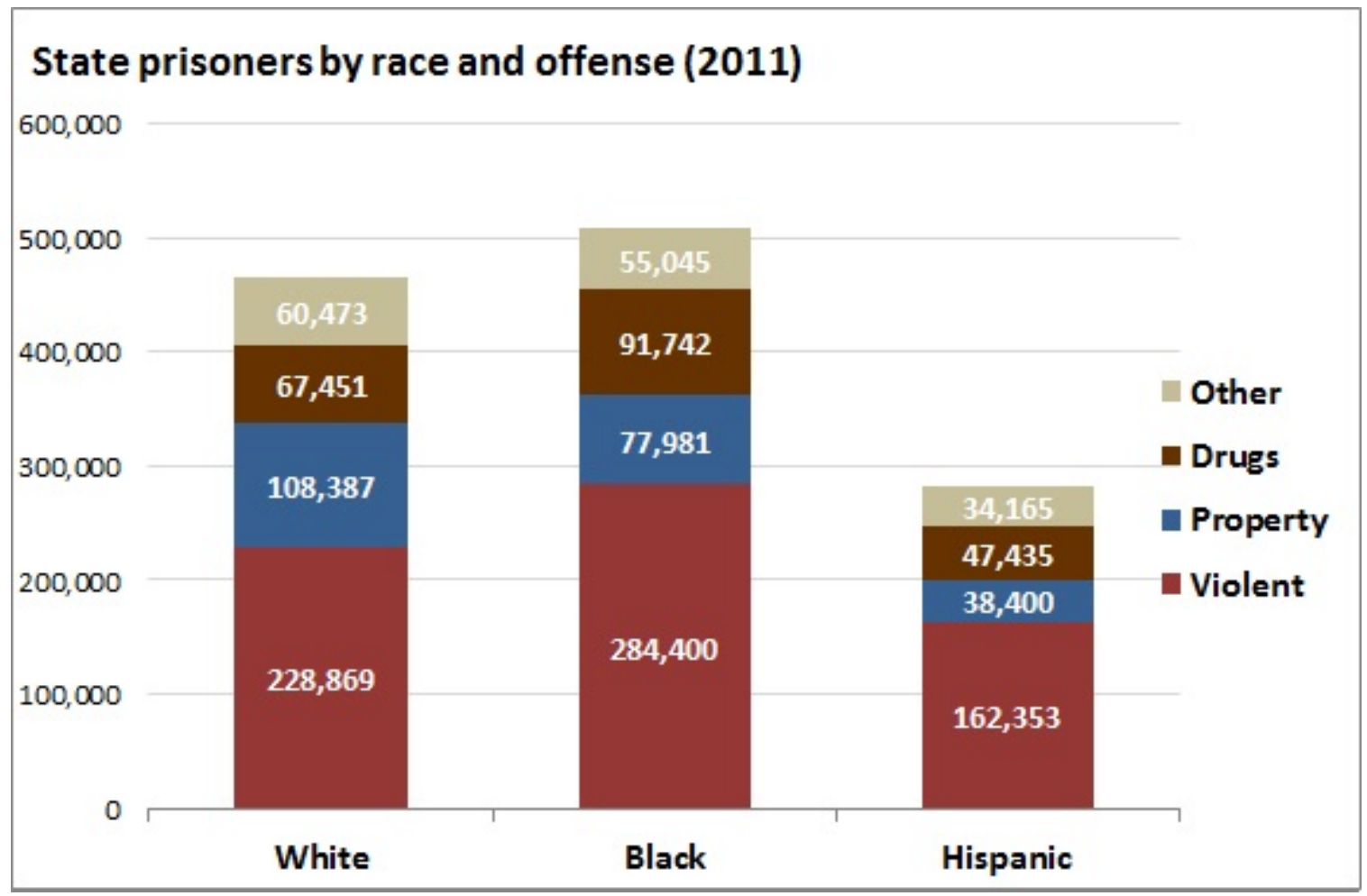

Figure 5: State prisoners by race and offense 2011 (Walden, 2013).

\section{Numbers in School PreK-12}

\section{COST OF EDUCATION}

Figure 6 below provides projections of number of in the United States It then breaks down by age where we can expect our children to be in fall 2018, about 1.4 million children are expected to attend public prekindergarten and 3.6 million are expected to attend public kindergarten (47).

\begin{tabular}{|c|c|c|c|c|c|c|c|c|c|c|c|c|c|c|c|c|c|c|}
\hline $\begin{array}{l}\text { Number } \\
\text { (in } \\
\text { million) }\end{array}$ & 2010 & 2011 & 2012 & 2013 & 2014 & 2015 & 2016 & 2017 & 2018 & 2019 & 2020 & 2021 & 2022 & 2023 & 2024 & 2025 & 2026 & 2027 \\
\hline $\begin{array}{l}\text { All } \\
\text { children }\end{array}$ & 74.1 & 73.9 & 73.7 & 73.6 & 73.6 & 73.6 & 73.7 & 73.7 & 73.8 & 73.9 & 74.1 & 74.3 & 74.5 & 74.7 & 74.9 & 75.0 & 75.2 & 75.5 \\
\hline \multicolumn{19}{|l|}{ Age } \\
\hline $\begin{array}{l}\text { Ages } 0- \\
5\end{array}$ & 24.2 & 24.1 & 24.0 & 23.9 & 23.9 & 24.0 & 23.9 & 23.9 & 24.3 & 24.5 & 24.6 & 24.8 & 24.9 & 25.0 & 25.1 & 25.2 & 25.3 & 25.3 \\
\hline $\begin{array}{l}\text { Ages 6- } \\
11\end{array}$ & 24.6 & 24.5 & 24.6 & 24.7 & 24.7 & 24.7 & 24.7 & 24.7 & 24.5 & 24.4 & 24.3 & 24.4 & 24.5 & 24.6 & 24.8 & 24.9 & 25.1 & 25.2 \\
\hline $\begin{array}{l}\text { Ages } \\
12-17\end{array}$ & 25.1 & 25.1 & 25.0 & 25.0 & 25.0 & 25.0 & 25.1 & 25.1 & 25.0 & 25.0 & 25.2 & 25.1 & 25.1 & 25.1 & 25.0 & 24.9 & 24.8 & 24.9 \\
\hline
\end{tabular}




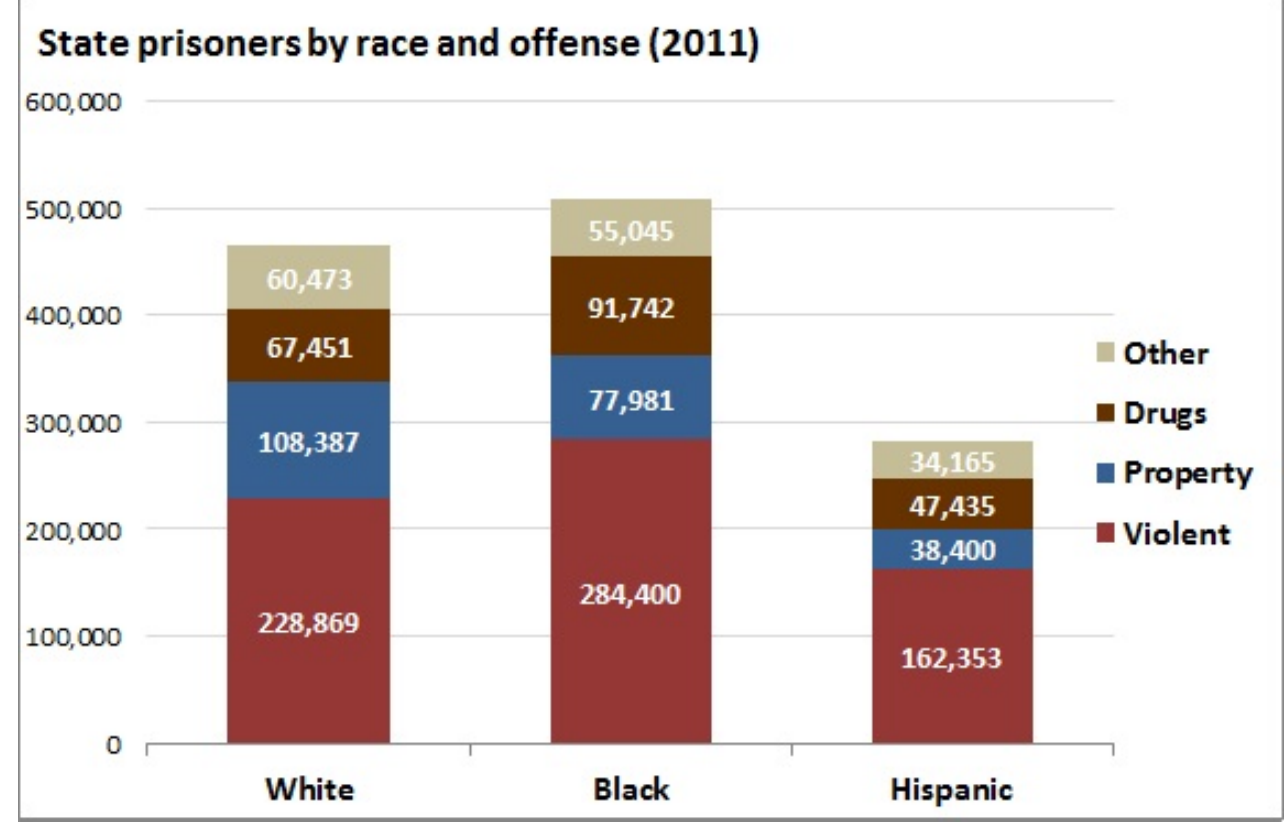

Figure 5: State prisoners by race and offense 2011 (Walden, 2013).

\section{Numbers in School PreK-12}

\section{COST OF EDUCATION}

Figure 6 below provides projections of number of in the United States It then breaks down by age where we can expect our children to be in fall 2018, about 1.4 million children are expected to attend public prekindergarten and 3.6 million are expected to attend public kindergarten (47)

About 4.0 million public school students are expected to enroll in 9th grade in fall 2018 . Students typically enter American high schools in 9th grade (47).

In fall 2018, about 56.6 million students will attend elementary and secondary schools, including 50.7 million students in public schools and 5.9 million in private schools. Of the public school students, 35.6 million will be in prekindergarten through grade 8 and 15.1 million will be in grades 9 through 12 . The fall 2018 public school enrollment is expected to be slightly higher than the 50.6 million enrolled in fall 2017 and is higher than the 49.5 million students enrolled in fall 2010. Total public elementary and secondary enrollment is projected to increase between fall 2018 and fall 2027 to 52.1 million (47).

Of the projected 50.7 million public school students entering prekindergarten through grade 12 in fall 2018, White students will account for 24.1 million. The remaining 26.6 million will be composed of 7.8 million Black students, 14.0 million Hispanic students, 2.6 million Asian students, 0.2 million Pacific Islander students, 0.5 million American Indian/Alaska Native students, and 1.6 million students of Two or more races. The percentage of students enrolled in public schools who are White is projected to continue to decline through at least fall 2027 along with the percentage of students who are Black, while the percentage of students who are Hispanic Asian, and of Two or more races are projected to increase (47).

\section{Teachers}

Public school systems will employ about 3.2 million full-time-equivalent (FTE) teachers in fall 2018, such that the number of pupils per FTE teacher - that is, the pupil/teacher ratio-will be 16.0. This ratio has remained consistent at around 16.0 since 2010. A projected 0.5 million FTE teachers will be working in private schools this fall, resulting in an estimated pupil/teacher 
ratio of 12.3 , which is similar to the 2017 ratio of 12.2 , but lower than the 2010 ratio of 13.0 (47).

\section{Expenditures}

Current expenditures for public elementary and secondary schools are projected to be $\$ 654$ billion for the 2018-19 school year. The current expenditure per student is projected to be $\$ 12,910$ for the $2018-19$ school year (47).

\section{Background information from prior school years: Elementary and Secondary Schools and Districts}

In $2015-16$, there were about 13,600 public school districts with close to 98,300 public schools, including about 6,900 charter schools. In fall 2015, there were about 34,600 private schools offering kindergarten or higher grades (47).

In 2016-17, about one-third (32\%) of districts reported that all of their Career and Technical Education (CTE) programs were structured as career pathways that align with related postsecondary programs, and an additional one-third (33\%) reported that most of their programs were structured this way (47).

In fall 2017, about 50.7 million students will attend public elementary and secondary schools. Of these, 35.6 million will be in prekindergarten through grade 8 and 15.1 million will be in grades 9 through 12. An additional 5.2 million students are expected to attend private elementary and secondary schools (1).

About 41\% of inmates in the Nation's State and Federal prisons and local jails in 1997 and 31\% of probationers had not completed high school or its equivalent. In comparison, $18 \%$ of the general population age 18 or older had not finished the 12th grade (Education, 2003).

Between 1991 and 1997, the percent of inmates in State prison without a high school diploma or GED remained the same - 40\% in 1997 and 41\% in 1991. Of inmates in State prisons, 293,000 in 1991 and 420,600 in 1997 had entered prison without a high school diploma, a $44 \%$ increase (Education, 2003).

\section{How much is spent on U.S. education by jurisdiction}

Education spending accounted for less than 3 percent of the $\$ 3.8$ trillion in federal spending for 2015. Although this may not sound like much when compared to the $33 \%$ that went toward Social Security, Unemployment and Labor or the $27 \%$ for Medicare and Health, it still represents billions of dollars (26). Federal money is allocated to individual states and covers elementary, secondary, vocational, higher education, research and training (26).

\section{Spending by local, state and federal government}

State and local government provide the majority of funding for elementary and secondary education. According to the National Center for Education Statistics, in 2014 roughly 45\% of funding was provided by state government, $47 \%$ was provided by local sources and 8 percent came from the federal government (26).

Federal funding: This money is distributed to the states through the U.S. Department of Education and annually amounts to more than $\$ 40$ billion for elementary and postsecondary education. From 2009 to 2015 federal funds allocated for Improving Teacher Quality State Grants has remained relatively steady, from $\$ 2.3$ billion to $\$ 2.35$ billion annually. Money 
allocated for postsecondary Pell Grants more than doubled, from $\$ 19.3$ billion in 2009 to $\$ 41.6$ billion in 2011. Since then, the amount of federal spending for Pell Grants has declined from $\$ 41.4$ billion in 2012 to $\$ 35.6$ billion in 2013 , to about $\$ 30$ billion in 2014 and finally around $\$ 28.8$ billion in 2015 (26).

State funding: This funding for elementary and secondary schools is generated primarily through income and sales taxes. However, some states rely heavily on property taxes to fund K12 schools. Every state legislature determines the raising and eventual distribution of money. The amount each school receives is based on different formulas like number of students and demonstrated need. Schools in poor neighborhoods often receive more attention to make up for limited local sources of funding (26).

Local funding: This money comes largely through tax assessments on residential and commercial property within individual school districts. In the wealthier parts of town, schools receive sufficient funds to ensure that their schools are properly equipped for students. In lessaffluent neighborhoods, schools are often underfunded and may not get the resources they need (26).

\section{Funding bottom line}

On average, it costs $\$ 10,615$ to send a kid to public school for a year in 2010. [That's federal, state and local government spending combined] (39).

Total expenditures for public elementary and secondary schools in the United States in 201314 amounted to $\$ 634$ billion, or $\$ 12,509$ per public school student enrolled in the fall (in constant 2015-16 dollars (U.S. Department of Education, 2017).

To think about the value of $\$ 122,000$ over 13 years, it is useful to break the number up. Average Alex spends close to six hours a day in class for up to 180 days per year - a total of slightly over 1,000 hours of class time. What is the investment per student per instructional hour?

It turns out that the average expenditure per student hour in California is just a bit over the minimum wage: about $\$ 8 /$ hour. This way of thinking about our investment in education is provocative, and has some advantages. Time in school is a precious commodity, but we rarely put a value on it. Having a dollars-per-hour approximation of the cost of kids' time allows us to re-imagine students as workers, and teachers as managers. The $\$ 8$ per hour rule of thumb can also help to spur discussion about the real cost of activities that use time - some discussion prompts are suggested below [The authors understand the minimum wage is in a flux upward (41).

\section{IMPACT ON INCARCERATION ON EDUCATION AND PRISONS ON STATE AND LOCAL BUDGETS}

\section{Introduction}

Nearly $75 \%$ of imprisonment spending happens at the state level, where dollars are drawn from a general fund that is meant to pay for a range of public needs, including health care, housing, public assistance, and education (1). Figure 7 provides a worrying example of the rate of expenditure that's risen abnormally. The report also put forth some concerning statistics about the number of incarcerated Americans. About three decades earlier, there were around 500,000 inmates in jails spread across the U.S. However, that number has grown to nearly 2.1 million. Compared to the average growth rate of the American population, the number of American citizens being sent to jail is alarmingly high. The number of people being sent to jail 
has surged more than four-fold during the last three decades, as compared to growth rate of the U.S. population, reported the Washington Post.

\section{Prison vs Education Costs in the United States Thousand U.S. dollars, 2010}

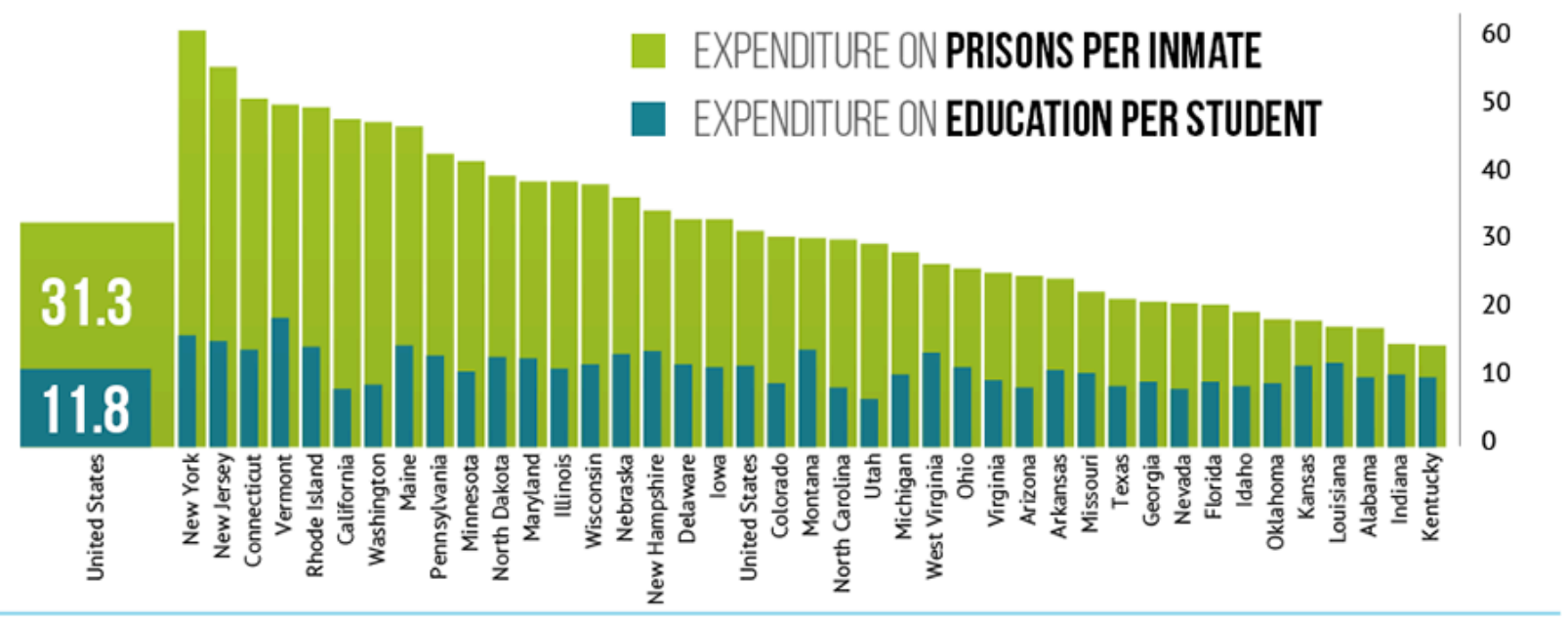

Knoema

Sources: Vera Institute of Justice, U.S. Census Bureau

Figure 7: Expenditures per inmate and student by state 2010 (28).

The relative modern day cost of incarceration in the US relative to public expenditures on elementary-secondary education strongly supports social policy planning that puts education first. Assuming that the total number of people imprisoned in the United States was 1.2 million in 2010, the average per-inmate cost was $\$ 31,286$ and ranged from $\$ 14,603$ in Kentucky to $\$ 60,076$ in New York. In contrast, the US government spent $\$ 602$ billion on the nearly 50 million elementary-secondary students in public schools in the US in 2010 , or about $\$ 12,800$ per student, according to the US Census Bureau. This is more than two times less than was spent on average per inmate (28).

The bar graph at Figure 8 is more representative in its aggerate form showing the difference of funding.

Percentage change in PK-12 current expenditures and state and local corrections current expenditures from 1979-80 to 2012-13

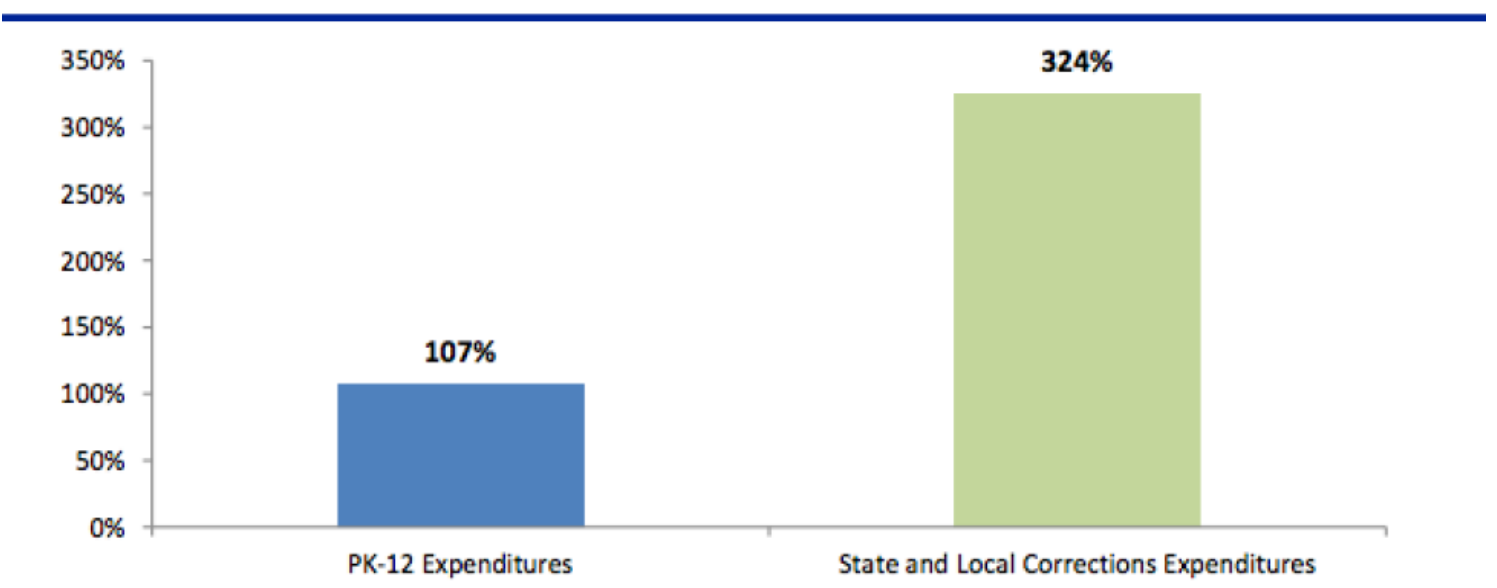

Figure 8: PK-12 expenditures versus correctional expenditures 1979-2013 (80). 
Spending money on prisons is a particularly poor investment relative to spending money on education. Some urban neighborhoods have seen large swaths of their population relocated to prisons in the past several decades. These so-called million-dollar blocks - where taxpayers have spent a million dollars or more keeping former neighborhood residents locked up in prison - can be desolate places, full of "children who are missing their parents, households that are missing their breadwinners, [and] families who must support returning offenders who are now much harder to employ," as my colleague Emily Badger wrote last year. And as families in these neighborhoods are hollowed out by aggressive incarceration policies, children have an even harder time escaping their circumstances, creating a vicious cycle (Ingraham, 2016 as cited in 21).

\section{Linkages between education and incarceration Linkage}

There is a definite linkage between education and incarceration! Researchers have found connections between poor educational outcomes and incarceration. Among state prison inmates, available data suggests that two-thirds have not completed high school (BJS, 2009 as cited in 50). Young black males between the ages of 20 and 24 who do not have a high school diploma (or an equivalent credential) have a higher chance of being incarcerated than of being employed (Neal and Rick 2014).6 Researchers have estimated that a 10\% increase in high school graduation rates may result in 9 percent decline in criminal arrest rates (Lochner and Moretti 2004). A variety of studies have suggested that investing more in education, particularly targeted toward at-risk communities, could achieve crime reduction without the heavy social costs that high incarceration rates impose on individuals, families, and communities (Belfield et al. 2006; Reynolds et al. 2001; Heckman et al. 2010).

Correctional populations report lower educational attainment than do those in the general population. An estimated $40 \%$ of State prison inmates, $27 \%$ of federal inmates, $47 \%$ of inmates in local jails, and $31 \%$ of those serving probation sentences had not completed high school or its equivalent while about $18 \%$ of the general population failed to attain high school graduation (46).

Nearly one and a half million individuals are housed in adult correctional facilities in the United States. The United States Department of Justice reports that "the typical offender is undereducated, unemployed and living in poverty before incarceration." (59).

Inside our prisons, $19 \%$ percent of adult inmates are illiterate, and up to $60 \%$ are functionally illiterate. In contrast to this, our national adult illiteracy rate stands at $4 \%$, with up to $23 \%$ functionally illiterate (87).

Correctional populations less educated than the general population (46).

Correctional populations - including State and Federal prison inmates, local jail inmates, and probationers - differ substantially in educational attainment from persons 18 and older in the general civilian noninstitutional population (46).

\section{Expenditures while incarcerated}

Over 9 in 10 State prisons provided educational programs for their inmates. Half of State prison inmates reported they had participated in an educational program since their most recent admission to prison. About a quarter of State inmates had taken basic education or high school level courses, and almost a third, vocational training (Education, 2003). 
Although the percentage of State prison inmates who reported taking education courses while confined fell from $57 \%$ in 1991 to $52 \%$ in 1997, the number who had participated in an educational program since admission increased from 402,500 inmates in 1991 to 550,000 in 1997 (Education, 2003).

Over the past three decades, state and local government expenditures on prisons and jails have increased about three times as fast as spending on elementary and secondary education.

This increase in corrections spending has been driven by - among other factors1 — an increase in the number of people incarcerated in prisons and jails. The United States has only 5 percent of the world's population but more than $20 \%$ of the world's incarcerated population (Lee 2015 as cited in 55).

Linkages exist between educational attainment and incarceration. For example, two-thirds of state prison inmates have not completed high school (BJS 2009). Young black men between the ages of 20 and 24 who do not have a high school diploma (or an equivalent credential) have a greater chance of being incarcerated than of being employed (Neal and Rick 2014 as cited in 55).

Over the past three decades, state and local government expenditures on prisons and jails have increased at a much faster pace than state and local spending on elementary and secondary education and postsecondary education. All too often, children growing up in poor communities not only do poorly in school but also are disproportionately arrested and incarcerated during their teen-age and young adult years. Researchers at Columbia University found that a disproportionate number of the upwards of two million people in U.S. prisons and jails come from disadvantaged neighborhoods in the country's biggest cities; the authors coined the term "million dollar blocks" to refer to places where the concentration of incarcerated individuals is so dense that states are spending over a million dollars a year to incarcerate the residents of a single city block (Columbia University, 2006 as cited in 55).

\section{Education vs. Incarceration and cost.}

The side effects to incarceration over education: In the United States, youth of color caught in the crossfire of the war on drugs are frequently subject to persecution, incarcerated and denied access to education opportunities. The irony is that the war on drugs is often defended as a necessary policy to protect the nation's young people. In reality, rather than protecting youth, the drug war has resulted in the institutionalized persecution of Black, Latino and Native American young people. While more and more young men and women of color are being ushered into the criminal justice system under the guise of fighting drugs, resources for educating youth are diminishing and barriers to education restrict students with drug convictions from receiving higher education (8).

Many School Districts had to take a hard looks at trimming its 2010-11 budgets in the wake of states budget forecast. It appears that legislators are pulling back on education funding and refusing to put emphasis on education reform as an urgent priority. These types of budget forecasts speak to fundamentally flawed views regarding the importance of improving the nation's education system (8).

Tough-on-crime laws implemented in the 1980s as part of America's so-called war on drugs are largely responsible for the country's exploding prison population. To be sure, the Justice Department has recently started reforming the criminal justice system - in part, by ensuring low-level drug offenders don't end up with lengthy prison sentences in the future (11). 
Could this expenditure be of better use while the individuals where in school obtaining their education?

\section{What Is the True Cost of Incarceration?}

The overall costs for corrections services must also account for salary and benefit increases for the more than 15,000 Pennsylvania prison employees. However, according to the Vera Institute of Justice, determining the total cost of state prisons requires accounting for expenditures in all areas of government that support the prison system-not just those within the corrections budget. The additional costs passed on to taxpayers can include expenses that are centralized for administrative purposes (such as employee benefits and capital costs) and services for inmates funded through other agencies.

Prison costs outside the Pennsylvania DOC's budget include the following:

- Underfunded pension contributions

- Underfunded retiree health care contributions

- Statewide administrative costs

- Increased inmate health care costs

- Increased expenditures in inmate education and training

- Capital costs (29).

\section{Introduction}

\section{WHY DIFFERENCE BETWEEN EDUCATION AND INCARCERATION COSTS}

Why is the United States the world leader in sending citizens to prison? In 1992, there were 1.3 million inmates in America's prisons and jails; by two decades later, a million more had been added (the data in this article are taken from the Bureau of Justice Statistics unless indicated otherwise). The majority of those-around $60 \%$-are in state prisons, where most people who commit crimes end up. Only around $10 \%$ are in federal prisons, despite the attention those prisons receive; the rest are held in local jails. And that doesn't include the millions more on probation and parole. At the end of 2011, there were 2.2 million Americans incarcerated, 854,000 on parole, and almost 4 million on probation, meaning just under 7 million Americans-or one out of every 34 adults-were being supervised by the criminal-justice system (Waldman, 2013).

\section{Budgeting}

As the economic downturn limited all state spending in the fiscal year 2008-2009, the share of general-fund money going to incarceration grew as expenditures in every other category ... save public assistance - declined (1).

How is school success affected by these policy choices and spending patterns? There is no definitive way to know what the previous spending cuts have meant for Los Angeles schools, but we do know that in Los Angeles, $67 \%$ of low-performing schools are in neighborhoods with the highest incarceration rates. By contrast, $68 \%$ of the city's high-performing schools are in neighborhoods with the lowest incarceration rates (1).

In a few select neighborhoods, the heavy investment in incarceration over education correlates with the lowest-performing schools. These neighborhoods send more individuals to prison than to college -- reflecting the pattern of dollars invested. The relationship has not yet been shown to be causal, but we do see a correlative effect between education and incarceration. If states were to properly invest in reopening schools, keeping quality teachers, maintaining sensible classroom sizes, and sustaining the affordability of higher education, it's quite possible -- particularly for economic crimes like low-level drug dealing -- we would not need to 
imprison so many people and could stop sinking our valuable taxpayer dollars into an investment that has demonstrated scant return (1).

Many School Districts had to take a hard looks at trimming its 2010-11 budgets in the wake of states budget forecast. It appears that legislators are pulling back on education funding and refusing to put emphasis on education reform as an urgent priority. These types of budget forecasts speak to fundamentally flawed views regarding the importance of improving the nation's education system (8).

\section{Drug Policy}

The side effects to incarceration over education: In the United States, youth of color caught in the crossfire of the war on drugs are frequently subject to persecution, incarcerated and denied access to education opportunities. The irony is that the war on drugs is often defended as a necessary policy to protect the nation's young people. In reality, rather than protecting youth, the drug war has resulted in the institutionalized persecution of Black, Latino and Native American young people. While more and more young men and women of color are being ushered into the criminal justice system under the guise of fighting drugs, resources for educating youth are diminishing and barriers to education restrict students with drug convictions from receiving higher education (8).

Tough-on-crime laws implemented in the 1980s as part of America's so-called war on drugs are largely responsible for the country's exploding prison population. To be sure, the Justice Department has recently started reforming the criminal justice system - in part, by ensuring low-level drug offenders don't end up with lengthy prison sentences in the future (11).

Clearly, in the past few years researchers have done extraordinary work calculating the dollar costs of imprisonment. States are recognizing that because $60 \%$ of the people who are locked up are there for non-violent offenses and that one quarter of all people behind bars are there for non-violent drug offenses, prisons can be safely downsized and the savings can be reinvested in programs proven to help create safe communities.

\section{Costs rising even as prison population decreases}

The surge in spending poses a number of questions about the country's system of incarceration, especially given that the overall rate for violent and property crimes has actually declined $45 \%$ during the past two decades.

The prison population is aging quickly, and older inmates cost prisons more because they require more care and medical treatment (11).

"Mass incarceration does not make us safer. The report comes after former U.S. Education Secretary Arne Duncan last September called on states and communities to invest in teachers rather than prisons by finding alternative paths for non-violent offenders outside of incarceration. The $\$ 15$ billion that could be saved by finding alternate paths to incarceration for just half of non-violent offenders is enough to give a $50 \%$ raise to every teacher and principal working in the highest-need schools and communities across the country (13).

There is an indirect correlation between educational attainment and arrest and incarceration rates, particularly among males, the report finds. According to the most recent data from the U.S. Bureau of Justice, $56 \%$ of federal inmates, $67 \%$ of inmates in state prisons, and $69 \%$ of inmates in local jails did not complete high school. Additionally, the number of incarcerated individuals without a high school diploma is increasing over time (17). 
So, if fewer crimes are being committed, why are we spending more on prisons? Federal and state policies -- such as mandatory sentencing and repeat-offender laws -- have actually led to an explosion in the country's incarceration rate, which is driving up spending (36).

At a time when more than half of Americans are willing to pay higher taxes to support education, states are spending extraordinary amounts to lock people up, even though incarceration has been shown to make us less safe, and is significantly more expensive, than community-based alternatives (29).

"What does it say about any state that focuses more on prison uniforms than on caps and gowns?" -Former California Governor Arnold Schwarzenegger (29).

\section{High School Dropout Rate}

Two-thirds of state prisoners have not completed high school and some findings suggest that black men between the ages of 20 to 24 lacking a high school diploma may have a better chance of going to prison than getting a job, according to the DOE. students (DeCourcey, 2016 as cited in 20).

"Dropping out of school does not automatically result in a life of crime, but high school dropouts are far more likely than high school graduates to be arrested or incarcerated," Wise said (17).

The link between a poor education and incarceration is borne out in data. Dropouts are 3.5 times more likely to be arrested than high school graduates. Nationally, $68 \%$ of all males in prison do not have a high school diploma. Only $20 \%$ of California inmates demonstrate a basic level of literacy, and the average offender reads at an eighth-grade level (19).

U.S. Secretary of Education John King said the report should serve as an eye-opener for state and local governments. He added that the administration should take a long, hard look at where the money is being spent and try to restructure their priorities. He urged the governments to channel more funds towards education but did not say whether funds meant for the correctional facilities should be diverted (25).

Two-thirds of state prisoners have not completed high school and some findings suggest that black men between the ages of 20 to 24 lacking a high school diploma may have a better chance of going to prison than getting a job, according to the DOE. students (DeCourcey, 2016 as cited in 20).

How costly is the decision to drop out of high school? Consider a few figures about life without a diploma? The average dropout can expect to earn an annual income of $\$ 20,241$, according to the U.S. Census Bureau. That's a full $\$ 10,386$ less than the typical high school graduate, and $\$ 36,424$ less than someone with a bachelor's degree. The challenges hardly end there, particularly among young dropouts. Among those between the ages of 18 and 24, dropouts were more than twice as likely as college graduates to live in poverty according to the Department of Education. Dropouts experienced a poverty rate of 30.8 percent, while those with at least a bachelor's degree had a poverty rate of 13.5 percent (34).

One year at Princeton University: $\$ 37,000$. One year at a New Jersey state prison: $\$ 44,000$ (Resnick, 2011). 
The percentage of high school dropouts among 16- to 24-year-olds declined from $10.9 \%$ in 2000 to 6.1 percent in 2016. Reflecting the overall decline in the dropout rate between 2000 and 2016, the rates also declined for White, Black, and Hispanic students (47).

According to the Bureau of Justice Statistics report provides light on the connection between educational attainment and incarceration. The United States has only 5 percent of the world's population yet more than $20 \%$ of the world's incarcerated population. Two-thirds of state prison inmates have not completed high school. One study also shows young black men between the ages of 20 and 24 who do not have a high school diploma or an equivalent credential have a greater chance of being incarcerated than employed. Researchers have estimated that a 10\% increase in high school graduation rates results in a 9 percent decline in criminal arrest rates (11).

Records indicate that the majority of the inmates are high school dropouts. According to the report, about two-thirds of prisoners housed in American jails haven't completed high school, strongly indicating that lack of education could be a major reason these people took to crime, reported Education World (as cited in 25).

Among dropouts between the ages of 16 and 24, incarceration rates were a whopping 63 times higher than among college graduates, according to a study by researchers at Northeastern University. To be sure, there is no direct link between prison and the decision to leave high school early. Rather, the data is further evidence that dropouts are exposed to many of the same socioeconomic forces that are often gateways to crime (34).

In addition to the estimated $\$ 18.5$ billion savings related to national crime, the report also projects that the U.S. economy would benefit by as much as $\$ 1.2$ billion in additional annual earnings from a 5-percentage point increase in the high school male graduation rate (17).

Another study (34) found that as a result - when compared to the typical high school graduate - a dropout will end up costing taxpayers an average of \$292,000 over a lifetime due to the price tag associated with incarceration and other factors such as how much less they pay in taxes (34).

Education (2003) 68\% of state prison inmates did not receive a high school diploma. About $26 \%$ of state prison inmates said they had completed the GED while serving time in a correctional facility.

The groups of state prison inmates who had not completed high school or the GED included $40 \%$ of males and $42 \%$ of females $27 \%$ of whites, $44 \%$ of blacks, and $53 \%$ of Hispanics $52 \%$ of inmates 24 or younger and $35 \%$ of inmates 45 or older $61 \%$ of noncitizens and $38 \%$ of U.S. citizens $59 \%$ with a speech disability, $66 \%$ with a learning disability, and $37 \%$ without a reported disability $47 \%$ of drug offenders $12 \%$ of those with military service and $44 \%$ with no military service (Education, 2003).

\section{Introduction}

\section{VALUE ADDED: EDUCATION V. INCARCERATION}

Education's goal is to provide a viable citizen. Where do we get a return on investment, one who is educated or one who is in jail? Important fact (return on investment)

$$
\text { Education }=\text { value added } v . \text { Incarceration }=?
$$




\section{Education: Value added}

In 2016 , about $78.8 \%$ of 25 - to 34 -year-olds with a bachelor's or higher degree in the labor force had year-round, full-time jobs, compared with $72.3 \%$ of those with an associate's degree, $69.5 \%$ of those with some college education, $68.9 \%$ of those who completed high school, and $60.1 \%$ of those without a high school diploma or its equivalent. In 2017, the unemployment rate for 25- to 34-year-olds with a bachelor 's or higher degree (2.5 percent) was lower than the rate for young adults with some college (4.4 percent), those who had completed high school (7.2 percent), and those who had not completed high school (13.2\%) (47).

In 2016, for young adults ages 25-34 who worked full time, year-round, higher educational attainment was associated with higher median earnings; this pattern was consistent from 2000 through 2016. For example, in 2016, the median earnings of young adults with a bachelor's degree $(\$ 50,000)$ were $57 \%$ higher than those of young adult high school completers $(\$ 31,800)$. The median earnings of young adult high school completers were 26 percent higher than those of young adults who did not complete high school $(\$ 25,400)$. In addition, in 2016 , the median earnings of young adults with a master's or higher degree were $\$ 64,100$, some $28 \%$ higher than those of young adults with a bachelor's degree $(\$ 50,000)(47)$.

Will the increase in expenditure on education help bring down the number of arrests in America? King assures the increase in graduation is a surefire way to bring down crimes and criminals. He noted that a 10\% increase in high school graduation rates would result in a 9 percent decline in criminal arrest rates (25)

"Improving high schools will lead to increased graduation rates, which, in turn, will lower crime and incarceration rates and improve the nation's economy," Wise said. "Focusing on engaging students through digital learning, or the effective use of technology paired with quality teaching, will not only save the nation dollars, it will save students' futures." (17).

At the same time, researchers have estimated that a $10 \%$ increase in high school graduation rates may result in a 9 percent decline in criminal arrest rates (Lochner and Moretti 2004 as cited in 88).

The nation could save as much as $\$ 18.5$ billion in annual crime costs if the high school male graduation rate increased by only 5 percentage points, a 2013 report from the Alliance for Excellent Education finds. The report, Saving Futures, Saving Dollars: The Impact of Education on Crime Reduction and Earnings, examines and builds upon research that links lower levels of educational attainment with higher rates of arrests and incarceration. Support for the report was provided in part by State Farm ${ }^{\circledR}$ as part of a series of documents that demonstrates the economic benefits from improving high school graduation rates (17).

\section{Incarceration}

"For every prisoner there are costs and benefits to incarceration," said Ben Harris, a co-author of Ten Economic Facts about Crime and Incarceration in the United States. "For someone who has committed a violent offense, we as a society can agree it's worth putting this person in prison." (36).

We are paying 2.1 million people to not work more than we are paying those that are working. (35). Workers age 25 and over without a high school degree had median annual earnings of $\$ 27,612$ at the end of 2017 compared with $\$ 37,128$ for high school graduates without a college degree. College graduates with at least a bachelor's degree earned \$66,456 annually. College 
graduates with advanced degrees (a professional or master's degree or higher) earned a median average of $\$ 77,324(35)$.

\section{Recidivism}

Prison education, by cutting recidivism rates, saves $\$ 4$ to $\$ 5$ for each dollar spent. Though research on prison education is still lacking, studies that have tracked the relationship between recidivism and educational attainment generally point to reduced recidivism and better preparation for transition back into their communities and the workforce upon release (nearly 690,000 people walk out of prisons each year, and several million will mill through local jails). A college degree can help offset the enormous employment barriers formerly incarcerated people typically face (56).

A 2013 RAND Corporation study showed that participation in prison education, including both academic and vocational programming, was associated with an over $40 \%$ reduction in recidivism—saving $\$ 4$ to $\$ 5$ for each dollar spent (Chen, 2015 as cited in 37).

Social, psychological, and demographic factors correlate powerfully with recidivism. Most persons are released from prison into the community unskilled, undereducated, and highly likely to become involved in crime again. Rates of recidivism in the United States are extraordinarily high, ranging from $41 \%$ to $71 \% .3$ (52).

Kelly (2016 as cited in 15) states a 10\% increase in high school graduation rates would result in a 9 percent decline in criminal arrest rates.

The first BJS study that uses a 9-year follow-up period (2005-2014) to examine the recidivism patterns of released prisoners shows 5 out of 6 state prisoners were arrested within 9 years of their release, $68 \%$ of released state prisoners were arrested within 3 years, 79\% within 6 years, and $83 \%$ within 9 years. More than three quarter $(77 \%)$ of prisoners released for a drug offense were arrested for a non-drug crime within 9 years (74).
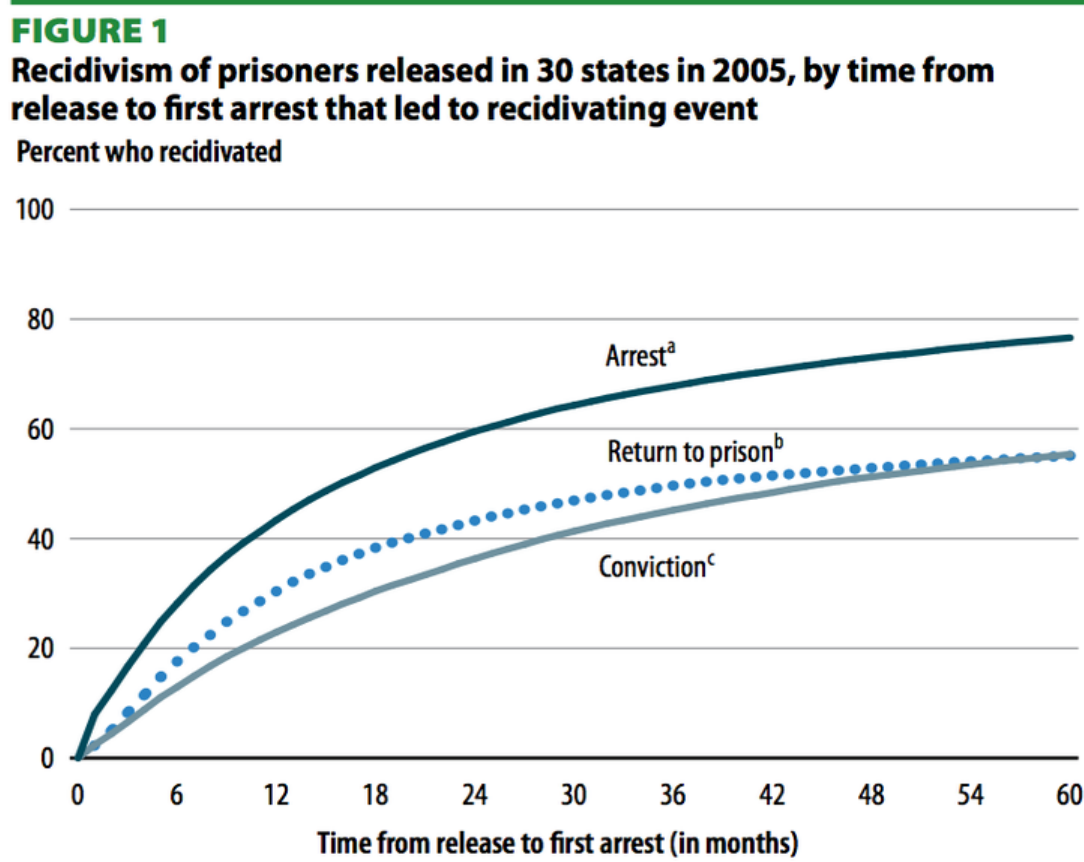

K2The above data tracked prisoners in 30 states, from 2005 until 2010. (Bureau of Justice Statistics as cited in 11). 
US prisons aren't very effective at rehabilitating inmates . Most convicts return to prison within five years of their release (11).

Costs rising even as prison population declines

L California was sued over prison overcrowding, and to comply with a federal court-imposed population cap, the Brown administration now keeps most lower-level offenders in county jails instead of state prisons. Additionally, voters in 2014 reduced penalties for drug and property crimes and last fall approved the earlier releases (7).

\section{Fixing the problems of education and incarceration}

More money must go to schools than to prisons before high-crime neighborhoods can truly be reformed (Hawkins, 2010 as cited in 15).

This tradeoff between education and incarceration is particularly acute at the community level. In many urban neighborhoods where millions of dollars are spent to lock up residents, the education infrastructure is crippled (Hawkins, 2010 as cited in 15).

"The nation needs to focus dollars and efforts on reforming school climates to keep students engaged in ways that will lead them toward college and a career and away from crime and prison," said Bob Wise, president of the Alliance for Excellent Education and former governor of West Virginia. "The school-to-prison pipeline starts and ends with schools." (17).

Spending on correctional facilities and education system are two completely different aspects. However, the report does hint that there is a strong correlation, and America could certainly benefit by reorganizing its priorities concerning the two (25). Each affects crime prevention. But the commonalities end there. Studies show that while quality education decreases crime, imprisonment actually increases crime; the ROI on prison spending is a losing proposition. In 2015, the United States placed 40th in the world in math and 25th in science. We need welleducated kids to become productive and law-abiding adults, and an educated workforce to remain competitive in a global economy. This requires significant investment in education (29).

The nation could save as much as $\$ 18.5$ billion in annual crime costs if the high school male graduation rate increased by only 5 percentage points, a 2013 report from the Alliance for Excellent Education finds. The report, Saving Futures, Saving Dollars: The Impact of Education on Crime Reduction and Earnings, examines and builds upon research that links lower levels of educational attainment with higher rates of arrests and incarceration. Support for the report was provided in part by State Farm as part of a series of documents that demonstrates the economic benefits from improving high school graduation rates (45).

"The nation needs to focus dollars and efforts on reforming school climates to keep students engaged in ways that will lead them toward college and a career and away from crime and prison," said Bob Wise, president of the Alliance for Excellent Education and former governor of West Virginia. "The school-to-prison pipeline starts and ends with schools." (45).

In addition to the estimated $\$ 18.5$ billion savings related to national crime, the report also projects that the U.S. economy would benefit by as much as $\$ 1.2$ billion in additional annual earnings from a 5 percentage point increase in the high school male graduation rate $(17,45)$.

In addition to examining total crime savings, the report projects the number of individual crimes that could be prevented by increasing the male high school graduation rate by 5 
percentage points, and finds that such an increase would decrease overall annual incidences of assault by nearly 60,000; larceny by more than 37,000 ; motor vehicle theft by more than 31,000 ; and burglaries by more than 17,000 . It would also prevent nearly 1,300 murders, more than 3,800 occurrences of rape, and more than 1,500 robberies (45).

Saving Futures, Saving Dollars notes the disparity between annual federal spending on students and inmates, and the findings are staggering; the United States spends $\$ 12,643$ to educate one student for one year versus the annual cost of $\$ 28,323$ to house one inmate. "If the nation made a comparable investment in effort and dollars in schools as it does in jails and prisons, the return would be decreased levels of criminal activity and incarceration as well as significant and life-changing impacts on the individual," the report notes (45).

There is an indirect correlation between educational attainment and arrest and incarceration rates, particularly among males, the report finds. According to the most recent data from the U.S. Bureau of Justice, $56 \%$ of federal inmates, $67 \%$ of inmates in state prisons, and $69 \%$ of inmates in local jails did not complete high school. Additionally, the number of incarcerated individuals without a high school diploma is increasing over time (45).

How is school success affected by these policy choices and spending patterns? There is no definitive way to know what the previous spending cuts have meant for Los Angeles schools, but we do know that in Los Angeles, $67 \%$ of low-performing schools are in neighborhoods with the highest incarceration rates. By contrast, $68 \%$ of the city's high-performing schools are in neighborhoods with the lowest incarceration rates (Hawkins, 2010 as cited in 15).

"Dropping out of school does not automatically result in a life of crime, but high school dropouts are far more likely than high school graduates to be arrested or incarcerated," Wise said (45).

Equity plays a large role in the connection between education level and crime rates; African Americans and Latinos are overrepresented in the criminal justice system. It is no coincidence, the report notes, that these same groups are disproportionately relegated to the nation's most troubled and low-performing schools (45).

The report finds that both school climate and discipline play large roles in whether a student graduates from high school and how likely a student is to be arrested or incarcerated. Suspended students, the report notes, are twice as likely to drop out as those who have not been suspended. African American high school students are at least twice as likely as their nonblack peers to be suspended (45).

The report recommends policy efforts at the national, state, and local levels to support school reforms to keep students on track to graduate from high school. It also notes that school-based interventions are needed to bring struggling students up to grade level and bring real-world experiences into the classroom to keep students engaged (45).

"Improving high schools will lead to increased graduation rates, which, in turn, will lower crime and incarceration rates and improve the nation's economy," Wise said. "Focusing on engaging students through digital learning, or the effective use of technology paired with quality teaching, will not only save the nation dollars, it will save students' futures." (45).

This spending disparity isn't inevitable. We have community-based programs that are significantly more effective, and cheaper, than incarcerating somebody. We could free up 
millions of dollars to invest in teachers and schools if we reduce our reliance on incarceration by shifting to community-based alternatives (29).

We must do this if we are to effectively spend our limited tax dollars. It's time we held elected officials accountable for decisions that waste money, make us less safe and penalize our kids with a second-rate education. If we are serious about creating safer and healthier communities, where our kids can find good jobs and build healthy lives as responsible adults, we cannot keep spending our limited resources on incarceration at the expense of funding the best education in the world. We need to get our priorities straight if we want to create a better, safer, future for ourselves and our kids (29).

Solution: According to a Philadelphia-based organization, Books Through Bars, the United States is ranked 21st in educational attainment globally, but number one in incarceration. The U.S. has 5 percent of the world's population, but $25 \%$ of the world's prisoners. While spending on incarceration continues to increase, funding for education at every level-from Head Start to colleges and universities-continues to be cut each year. States now spend four times more per capita to incarcerate than to educate. Change must occur. Consider one simple statistic: Nationally, about one in 10 young male high school dropouts is imprisoned, compared to 1 in 35 young male high school graduates. If we started spending more to educate people, we might just have fewer people to incarcerate (29).

Baskas (2015) says the percent of State and private prisons offering educational programs to their inmates increased from 1995 to 2000. In 1995, 88\% of State prisons and 72\% of private prisons provided educational programs; in 2000, $91 \%$ of State prisons and $88 \%$ of private prisons offered educational opportunities. During this period all Federal prisons offered courses.

Secondary education programs, which focus on preparing for the GED, were the most prevalent type of courses in 2000. Over 8 in 10 State prisons, almost all Federal prisons, about 7 in 10 private prisons, and over half of jails offered high school level classes. Next most common were classes in basic arithmetic and reading, with 8 in 10 State prisons, almost all Federal prisons, 6 in 10 private prisons, and 1 in 4 local jails offering basic education programs. (46).

In state prisons between 1995 and 2000, the percentages of prisons offering classes increased for basic education (76\% to $80 \%$ ), high school courses ( $80 \%$ to $84 \%$ ), and special education programs (33\% to $40 \%)$, while the percentage with college classes went down (31\% to 27\%) (46).

Vocational training, special programs designed to train participants for a job, were reported by $56 \%$ of State prisons, $94 \%$ of Federal prisons, $44 \%$ of private prisons, and $7 \%$ of local jails (46).

Prison isn't the most intellectually stimulating environment, but the dimmest corners of the criminal justice system may actually be a perfect place to liberate an otherwise wasted mind. A new initiative by the White House to issue Pell Grants to incarcerated students is about to test just how truly corrective our so-called corrections system can be (Chen, 2015 as cited in 37).

The plan to extend Pell Grant access in prisons is described as a "limited pilot program" authorized through a federal financial aid waiver program under the Higher Education Act. Incarcerated adults could apply for grants of up to $\$ 5,775$ for tuition and related expenses, at college-level programs offered in prison facilities nationwide. Designed to allow for studying long-term effects of education on recidivism, the program moves toward restoring access to 
Pell Grants for incarcerated people, which Congress removed in the mid-1990s (Chen, 2015 as cited in 37).

College behind bars remains a tough sell to some law-and-order conservatives-hence the charmingly titled counter-legislation, the "Kids Before Cons" Act. Generally, however, the idea of de-carcerating the prison population appeals to an ascendant libertarian streak among Republicans because, in fiscal terms, textbooks and professors yield better returns on investment than weight rooms and laundry duty (Chen, 2015 as cited in 37).

The criminal justice system unfortunately seems to be the main vehicle to treatment and other things for poor people and communities of color in the United States. But while we do have so many people locked up, and so many people criminalized, I do think we have a responsibility as a country to undo the mess we've gotten into (Chen, 2015 as cited in 37).

It's easy to get enthusiastic about the "corrections system" as a workshop to fix social undesirables, but many people never belonged anywhere near this broken system to begin with. Delivering long-denied educational opportunity behind bars isn't a process of "correcting" the flawed people inside but of correcting injustice that surrounds communities on the outside (Chen, 2015 as cited in 37).

\section{Redirecting investments to education}

Investments in education can reduce criminal activity by altering student behavior and improving labor market outcomes (CEA, 2016). Investments in early childhood education can lead to reduced incarceration later in life, in part through improving educational attainment (Currie, 2001). Though many factors contribute to student success, research indicates that teacher effectiveness is perhaps the most important in-school factor related to students' success in school (Rivkin et al., 2005). Further, research suggests that investing more in teacher salaries could result in an overall improvement in the quality of the teaching workforce and that higher salaries are associated with higher teacher retention (Dee and Wyckoff, 2015; Kelly, 2004; Guarino et al., 2006). Evidence also shows that education provides a pathway to help justice-involved people restore full participation in their communities. For example, one study found that incarcerated individuals who participated in high-quality correctional education - including postsecondary correctional education - were $43 \%$ less likely to return to prison within three years than those who did not participate in correctional education programs (Davis et al., 2013). Furthermore, researchers estimate that for every dollar invested in correctional education programs, four to five dollars are saved on three-year recidivism costs (Davis et al., 2013). King et al. (2005) have also suggested that "investments in drug treatment, interventions with at-risk families, and school completion programs are more costeffective than expanded incarceration as crime control measures." (55)

To shift our funding priorities, national and state policy-makers will have to choose costeffective criminal-justice policies and focus on public-safety strategies that curb crime and reserve more of our tax dollars for our children's education. engagement, and improved public -- safety outcomes for neighborhoods at risk of violence and victimization (1).

\section{Facts from the research}

- Fact 1: Crime rates have steadily declined over the past twenty-five years.

- Fact 2: Low-income individuals are more likely than higher-income individuals to be victims of crime.

- Fact 3: The majority of criminal offenders are younger than age thirty

- Fact 4: Disadvantaged youths engage in riskier criminal behavior. $(22,24,48)$. 
- Fact 5: Federal and state policies have driven up the incarceration rate over the past thirty years.

- Fact 6: The U.S. incarceration rate is more than six times that of the typical OECD nation.

- Fact 7: There is nearly a 70 percent chance that an African American man without a high school diploma will be imprisoned by his mid-thirties $(22,24,48)$.

- Fact 8: Per capita expenditures on corrections more than tripled over the past thirty years.

- Fact 9: By their fourteenth birthday, African American children whose fathers do not have a high school diploma are more likely than not to see their fathers incarcerated $(22,24,48)$.

- Fact 10: By their fourteenth birthday, African American children whose fathers do not have a high school diploma are more likely than not to see their fathers incarcerated $(22,24,48)$.

The incarceration rate in the United States is now at a historically unprecedented level and is far above the typical rate in other developed countries. As a result, imprisonment has become an inevitable reality for subsets of the American population. Today's high rate of incarceration is considerably costly to American taxpayers, with state governments bearing the bulk of the fiscal burden. In addition to these budgetary costs, current incarceration policy generates economic and social costs for both those imprisoned and their families $(22,24,48)$.

\section{The essential findings from this study were:}

1. Prisons should not be used with the expectation of reducing criminal behaviour.

2. On the basis of the present results, excessive use of incarceration has enormous cost implications.

3. In order to determine who is being adversely affected by prison, it is incumbent upon prison officials to implement repeated, comprehensive assessments of offenders' attitudes, values, and behaviours while incarcerated.

4. The primary justification of prison should be to incapacitate offenders (particularly, those of a chronic, higher risk nature) for reasonable periods and to exact retribution (2).

5. "Budgets reflect our values, and the trends revealed in this analysis are a reflection of our nation's priorities that should be revisited," said U.S. Secretary of Education John B. King Jr. "For far too long, systems in this country have continued to perpetuate inequity. We must choose to make more investments in our children's future. We need to invest more in prevention than in punishment, to invest more in schools, not prisons." (13).

6. To shift our funding priorities, national and state policy-makers will have to choose cost-effective criminal-justice policies and focus on public-safety strategies that curb crime and reserve more of our tax dollars for our children's education (Hawkins, 2010 as cited in 15).

7. Americans often use the expression "put your money where your mouth is," and data on government spending shows that Americans increasingly put their money behind prisons instead of education. For the past 30 years, the U.S. has drastically increased the amount of tax payer money that funds prisons compared to money for schools and students (DeCourcey, 2016 as cited in 20).

8. "Budgets reflect our values, and the trends revealed in this analysis are a reflection of our nation's priorities that should be revisited," said King, according to a DOE press release. "For far too long, systems in this country have continued to perpetuate inequity. We must choose to make more investments in our children's future. We need to invest more in prevention than in punishment, to invest more in schools, not prisons." students (DeCourcey, 2016 as cited in 20). 
9. Our skyrocketing prison bill, in other words, is highly counterproductive. We could save money, reduce violent crime and increase economic activity - all by simply redirecting prison funds into smarter investments on education. But as things stand now, taxpayers are getting a raw deal on criminal justice spending when they could be getting a free lunch (Ingraham, 2016 as cited in 21).

10. U.S. has been spending at a higher rate on jails than it does on schools. A government report released Thursday indicated the government spends three times the rate on correctional facilities than the education system.

11. In the last three decades, the cost to maintain the correctional facilities spread across the country has increased primarily due to the steadily growing number of Americans in jails. The report adds that more Americans are increasingly being sentenced to a prolonged period of time in a prison owing to harsher sentencing laws and stringent law enforcement protocols (25)

12. As Americans examine the benefits of a well-educated 21st-century workforce, the 2.6 percent of annual federal spending that is allocated for education by the federal government continues to be scrutinized. With today's focus on Science, Technology, Engineering and Mathematics (STEM) courses, diversity programs to expand differentiated instruction and inclusive classrooms that embrace special education learners, it is crucial to maximize educational resources for the benefit of current and future generations. The resulting return on investment in education is vital for the United States to remain competitive in a global economy (26).

13. While findings varied widely across states, the increases in corrections expenditures nearly always outpaced those for education funding. In all states, increases in corrections expenditures outpaced increases in PK-12 education expenditures; and in all except two states (Massachusetts and New Hampshire), the rate of increase for corrections expenditures per capita outpaced the rate of increase for PK-12 education expenditures per pupil. At the postsecondary level, increases in corrections expenditures outpaced changes in higher education appropriations, both in total funding and in funding per person; in fact, 46 states actually had declines in higher education funding per FTE student (26).

14. Reducing incarceration rates and redirecting some of the funds currently spent on corrections in order to make investments in education that we know work - including significantly increasing teacher salaries for great teachers willing to work in hard-tostaff schools,14 increasing access to high-quality preschool (Heckman et al. 2010; Belfield et al. 2006; Reynolds et al. 2001 as cited in 26), providing greater educational opportunity for students seeking a higher education, and for those individuals who are incarcerated, providing access to high-quality correctional education - could provide a more positive and potentially more effective approach to both reducing crime and increasing opportunity among at-risk youth, particularly if in the PK-12 context the redirected funds are focused on high-poverty schools (Trostel 2015; Lochner and Moretti 2004 as cited in 26).

15. Is the level of prison spending really necessary or can the funds be better diverted to other more important avenues such as education? The answer is YES! (27)

16. We can't expect students to excel, to set and reach their goals, when we demonstrate with our spending choices that they aren't our priority. (29).M Research demonstrates that education is one of the soundest investments we can make, but we spend smaller portions of our budgets on it every year. If our kids and future actually are a priority, we need to reflect that in how we allocate limited resources. Yet, policymakers repeatedly send scarce tax dollars to one of the least effective investments - prisons (29).

17. Americans are reinforced to believe that individuals are largely in control of their own destiny. Hard work, sacrifice, and personal effort, we are told, determine what happens 
to us. But increasingly, the fundamental institutions of American society function unfairly, restricting access and opportunity for millions of people. The greatest example of this is the present-day criminal justice system (32).

In 2010, approximately 2.7 million children, or over 3 percent of all children in the United States, had a parent in prison (The Pew Charitable Trusts, 2010). As of 2007, an estimated 53\% of prisoners in the United States were parents of children under age eighteen, a majority being fathers (Glaze \& Maruschak, 2010 as cited in 48). Furthermore, it is not the case that these parents were already disengaged from their children's lives. For example, in 2007, approximately half of parents in state prisons were the primary provider of financial support for their children-and nearly half had lived with their children-prior to incarceration (ibid.). Furthermore, fathers often are required to pay child support during their incarceration, and since they make little to no money during their incarceration, they often accumulate child support debt.

\section{HOW TO CURB INCARCERATION THROUGH EDUCATION}

Crime rates in the United States have been on a steady decline since the 1990s. Despite this improvement, particular demographic groups still exhibit high rates of criminal activity while others remain especially likely to be victims of crime.

\section{Implications}

In 2018 Alabama was placed under court order to reduce overcrowding and it will cost $\$ 800,000,000$ to build prisons to solve the problem ... can we guess where the money will come from and what effects it will have on the state general and education funds? California was sued over prison overcrowding, and to comply with a federal court-imposed population cap, the Brown administration now keeps most lower-level offenders in county jails instead of state prisons. Additionally, voters in 2014 reduced penalties for drug and property crimes and last fall approved the earlier releases (7).

In order to correct this discrepancy, policies must be enacted that make education a priority over incarceration (8).

Investing more in increasing school success for disadvantaged children and youth could reduce disciplinary issues and reverse the school-to-prison pipeline. In addition, educational programs for incarcerated youth and adults could reduce recidivism and crime by developing skills and providing opportunities (13).

\section{Questions}

While writing this article several questions came to the authors' minds that require citizens input to government and the education community to address the conclusion of this article:

Why are the high school curriculum focused on preparation for college when only $20 \%$ of the jobs in the U.S. require a college degree? The education community and society have demeaned vocational training to the extent that students are taking out loans to go to college, dropping out or getting degrees that will take them years to pay off for years.

When the basis of everything we do in the U.S. is based on education, why is there always a lack of funding according to all research?

With the largest portion of the prisoners incarcerated for drugs why is our drug policies not decreasing those using drugs? 
An ancillary question can be is incarceration necessary for those sentenced or are there other methods based on severity of the drug conviction?

Why are we spending money educating prisoners who are serving death and life in prison sentences ... example Pell grants?

While providing high school education to those who do not have that degree is it effective when we have such a high rate of recidivism?

Another ancillary question would be are we providing them with job training? According to the latest labor figures the trades are lacking in applicants.

\section{First Step}

As the author was finishing his research Congress passed and the President signed a bill popularly known as "First Step." Among the provisions, the measure also would allow inmates to request reviews of their cases retroactively under the Fair Sentencing Act of 2010, which reduced the sentencing disparity between crack and powder cocaine. This provision would allow about 2,600 federal prisoners sentenced for crack cocaine offenses before late 2010 the opportunity to petition for a reduced penalty.

The bill enhances employment and training opportunities so that federal prisoners are better prepared to return to society. It gives judges more discretion when sentencing some drug offenders and eases mandatory minimum sentences.

The bill reduces the life sentence for offenders with three convictions, or "three strikers" to 25 years. It reduces the mandatory minimum sentence for felony drug offenses to 15 years from 20.

Another provision would allow about 2,600 federal prisoners sentenced for crack cocaine offenses before late 2010 the opportunity to petition for a reduced penalty.

The bill also encourages prisoners to participate in programs designed to reduce the risk of recidivism, with the reward being the accumulation of credits that can be used to gain an earlier release to a halfway house or home confinement to finish out their sentence. It prohibits prisoners convicted of a wide rage of serious offenses from earning such credits and gaining early release.

The measure also seeks to improve various aspects of prison life requiring prisoners to be placed with 500 driving miles of their home, by banning the shackling of pregnant women and guaranteeing free access to feminine hygiene products.

The bill only applies to federal prisoners, which house about 180,000 prisoners. That's fewer than $10 \%$ of all the inmates in the United States (Berry \& Collins, 2018, 101).

\section{CONCLUSION}

First step is a start. However, state and local prisoners are not entitled and the author does not see First Step answering the questions presented.

Do you think the U.S. should spend more money on education? No 5\%Yes 95\% (DeCourcey, 2016 as cited in 20). 
Prison and education "are the two most divergent paths one can take in life," Joseph Staten, an info-graphic researcher with Public Administration, says. Whereas one is a positive experience that increases lifetime earning potential, the other is a near dead end, which is why Staten found it striking that the lion's share of government funding goes toward incarceration (Resnick, 2011).

Gov. Bob Wise (2013) states "Improving the nation's high schools and engaging students will not only save the nation dollars, it will save students' futures” (88 para 1).

The author concludes with surety that the financing policies of education and incarceration are not providing the results intended.

\section{References}

1 retrieved from http://prospect.org/article/education-vs-incarceration

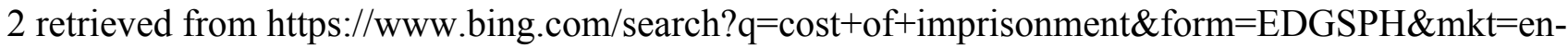
us\&httpsmsn=1\&refig=b547ed7342f2454a9a174c6fba3be6cc\&PC=HCTS\&sp=1\&ghc=1\&qs=AS\& $\mathrm{pq}=\mathrm{cos} \mathrm{t}+\mathrm{of}+\mathrm{impr} \& \mathrm{sc}=8-12 \& \mathrm{cvid}=\mathrm{b} 547 \mathrm{ed} 7342 \mathrm{f} 2454 \mathrm{a} 9 \mathrm{a} 174 \mathrm{c} 6 \mathrm{fba3be} 6 \mathrm{cc} \& \mathrm{cc}=\mathrm{US} \&$ setlang $=\mathrm{en}-\mathrm{US}$

3 retrieved from https://www.huffingtonpost.com/entry/mass-incarcerationcost_us_57d82d99e4b09d7a687fde21

4 retrieved from https://www.vera.org/publications/price-of-prisons-2015-state-spending-trends 5 retrieved from https://www.cbsnews.com/news/the-cost-of-a-nation-of-incarceration/

6 retrieved from

https://answers.yahoo.com/question/index; ylt=A2KLfS63ymFbCSkA5ECoCmVH; ylu=X3oDMT BybGY3bmpvBGNvbG8DYmYxBHBvcwMyBHZ0aWQDBHN1YwNzcg-?qid=20081010124546AASeozS\&guccounter=1

7 retrieved from http://www.latimes.com/local/lanow/la-me-prison-costs-20170604-htmlstory.html

\section{8 retrieved from https://sma Education vs. Incarceration: An American Dilemma}

9 retrieved from http://blacksonvillejacksonville.com/site/education-vs-incarceration-an-americandilemma/

10 retrieved from https://www.federalregister.gov/documents/2016/07/19/2016-17040/annualdetermination-of-average-cost-of-incarceration

11 retrieved from https://money.cnn.com/infographic/economy/education-vs-prison-costs/

12 retrieved from https://www.huffingtonpost.com/2013/02/07/federal-prisonpopulation_n_2638844.html

13 retrieved from https://www.ed.gov/news/press-releases/report-increases-spending-corrections-faroutpace-education

15 retrieved from https://www.businessinsider.com/r-us-spending-on-prisons-grew-at-three-timesrate-of-school-spending-report-2016-7

16 retrieved from http://prospect.org/article/education-vs-incarceration

17 retrieved from https://all4ed.org/press/crime-rates-linked-to-educational-attainment-new-alliancereport-finds/

18 retrieved from http://the hill.com/opinion/education/385520/taxing-our-kids-to-fund-prisons

19 retrieved from https://ed.stanford.edu/in-the-media/schools-v-prisons-educations-way-cut-prisonpopulation-op-ed-deborah-stipek 
20 retrieved from https://www.attn.com/stories/11025/us-spends-more-money-incarceration-thaneducation

21 retrieved from https://www.washingtonpost.com/news/wonk/wp/2016/07/07/the-states-thatspend-more-money-on-prisoners-than-college-students/?noredirect $=$ on\&utm_term $=.25 \mathrm{ddb} 33 \mathrm{eae} 04$

22 retrieved from https://www.brookings.edu/research/ten-economic-facts-about-crime-andincarceration-in-the-united-states/

23 retrieved from http://www.bard.edu/bpi/pdfs/crime_report.pdf24 https://ed.stanford.edu/in-themedia/schools-v-prisons-educations-way-cut-prison-population-op-ed-deborah-stipek

25 retrieved from https://www.inquisitr.com/3286999/us-prison-spending-schools-incarcerationjails-education-system/

26 retrieved from https://education.cu-portland.edu/blog/news/10-year-spending-trends-in-u-seducation/

27 retrieved from http://www.economywatch.com/in-the-news/infographic-prison-spending-vseducation-spending-in-us.27-10.htm

28 retrieved from

https://knoema.com/infographics/odgnikf/us-prison-costs-

grossly-exceed-public-education-spending

29 retrieved from https://inpublicsafety.com/2015/02/states-can-save-money-prioritizing-educationover-incarceration/

30 retrieved from https://www.brookings.edu/research/ten-economic-facts-about-crime-andincarceration-in-the-united-states/

31 retrieved from https://www.usnews.com/news/articles/2016-07-07/funding-for-prisons-increasedat-triple-the-rate-for-education

32 retrieved from http://www.reimaginerpe.org/node/2808

33 retrieved from http://www.prisonpolicy.org/reports/pie.html

34 retrieved from https://www.thebalancecareers.com/average-salary-information-for-us-workers2060808

35 retrieved from https://www.cbsnews.com/news/the-high-price-of-americas-incarceration-80billion/

36 retrieved from https://nces.ed.gov/fastfacts/display.asp?id=66

37 retrieved from https://www.thenation.com/article/prison-education-reduces-recidivism-by-over40-percent-why-arent-we-funding-more-of-it/

38 retrieved from https://www.npr.org/sections/money/2012/06/21/155515613/how-much-does-thegovernment-spend-to-send-a-kid-to-school

39 retrieved from https://nces.ed.gov/fastfacts/display.asp?id=66

40 retrieved from https://ed100.org/blog/cumulative-cost-of-k-12

41 retrieved from https://nces.ed.gov/fastfacts/display.asp?id=372

42 retrieved from http://www.angelfire.com/rnb/y/ratesusa.htm

43 retrieved from https://www.cnsnews.com/news/article/us-spending-least-186-million-dayincarcerate-illegal-aliens-more-195000-illegal-aliens

44 retrieved from https://www2.ed.gov/about/offices/list/ovae/pi/AdultEd/correctionaleducation.html 
45 retrieved from https://all4ed.org/press/crime-rates-linked-to-educational-attainment-new-alliancereport-finds/

46 retrieved from https://www.bjs.gov/content/pub/pdf/ecp.pdf

47 HTTPS://NCES.ED.GOV/FASTFACTS/DISPLAY.ASP?ID=372U.S.

48 retrieved from https://www.bls.gov/oes/current/oes332011.htm

49 retrieved from https://smartasset.com/mortgage/the-economics-of-the-american-prison-system

50 retrieved from https://deathpenaltyinfo.org/testimony-richard-c-dieter-esq-executive-directordeath-penalty-information-center-illinois-house-re

51 retrieved from https://www.forbes.com/sites/kellyphillipserb/2014/05/01/considering-the-deathpenalty-your-tax-dollars-at-work/\#511541f9664b

52 retrieved from http://www.prisontalk.com/forums/showthread.php?t=4850891

53 retrieved from https://definitions.uslegal.com/l/life-imprisonment/

54 retrieved from https://legal-dictionary.thefreedictionary.com/life+imprisonment

55 retrieved from https://www2.ed.gov/rschstat/eval/other/expenditures-correctionseducation/brief.pdf

56 retrieved from https://thecrimereport.org/2015/08/18/2015-08-if-prison-education-works-whydoesnt-us-embrace-it/

57 retrieved from http:/www.prisontalk.com/forums/showthread.php?t=485087

58 retrieved from https://www.bjs.gov/index.cfm?ty=tp\&tid=18

59 retrieved from https://www.prisonpolicy.org/scans/crime_report.pdf

60 retrieved from https://deathpenaltyinfo.org/costs-death-penalty

61. retrieved from https://www.themarshallproject.org/2014/12/17/six-reasons-the...

62 retrieved from www.foxnews.com/us/2010/03/27/just-cost-death-penalty-killer-state...

63 retrieved from http://www tcadp.org/wp...makes-the-Texas-death-penalty-so-expensive-print.pdf 64 retrieved from http://www.nbcnews.com/id/29552692/ns/us_news-crime_and_courts/t/executeor-not-question-cost/\#.W66AaPZFyL0

65 retrieved from https://www.aclunc.org/article/truth-about-life-without-parole-condemned-dieprison

66 retrieved from https://answers.yahoo.com/question/index?qid=20081010124546AASeozS

67 retrieved from https://www.hg.org/legal-articles/which-is-cheaper-execution-or-life-in-prisonwithout-parole-3161

68

https://www.bing.com/search?q=averag+salary+of $+\mathrm{a}+$ professional+fighter+in + the + united + states\&fo $\mathrm{rm}=\mathrm{EDGSPH} \& \mathrm{mkt}=\mathrm{en}-$

us\&httpsmsn=1\&refig=221b6a031868466dbf544fe5198a0269\&PC=HCTS\&sp=-

$1 \& \mathrm{pq}=$ averag + salary + of $+\mathrm{a}+$ professional + figh $\& \mathrm{sc}=0$ -

$36 \& \mathrm{qs}=\mathrm{n} \& \mathrm{sk}=\& \mathrm{cvid}=221 \mathrm{~b} 6 \mathrm{a} 031868466 \mathrm{dbf} 544 \mathrm{fe} 5198 \mathrm{a} 0269$

69 retrieved from http://www.mountain-news.com/news/crime_log/article_4f1e45f8-5630-11e0-

93da-001cc4c002e $0 . h t m l$ 
70 retrieved from

https://knoema.com/infographics/odgnikf/us-prison-costs-

grossly-exceed-public-education-spending

71 retrieved from https:/www.cbsnews.com/news/the-cost-of-a-nation-of-incarceration/

72 retrieved from https://answers.yahoo.com/question/index?qid=20170925113256AAdHRgT

73 retrieved from https://www.bls.gov/oes/current/oes332011.htm

74 retrieved from $54 \mathrm{https}: / /$ www.bjs.gov/index.cfm?ty=tp\&tid=18

75 retrieved from https://www.justice.gov/sites/default/files/jmd/legacy/2013/09/07/prisonsdetention.pdf

76 retrieved from http://www.crfb.org/blogs/us-spends-80-billion-year-incarceration/

77 retrieved from https://smartasset.com/mortgage/the-economics-of-the-american-prison-system

78 retrieved from https://www.coursehero.com/file/20214997/Capital-Punishment/

79 retrieved from https://www.wbir.com/article/news/local/death-penalty-vs-life-in-prison-thecosts/51-581820292

80 retrieved from https://legal-dictionary.thefreedictionary.com/life+imprisonment

81 retrieved from https://www.forbes.com/sites/kellyphillipserb/2014/05/01/considering-the-deathpenalty-your-tax-dollars-at-work/

$82 \mathrm{https}: / /$ www.bing.com/search?q=costs + of + death+row+prisoners\&mkt=en-

us\&httpsmsn=1\&refig $=\mathrm{d} 5 \mathrm{cf5b} 07 \mathrm{fd} 4 \mathrm{~d} 462 \mathrm{cb} 0 \mathrm{e} 6762126 \mathrm{a} 88 \mathrm{~b} 6 \mathrm{e} \& \mathrm{PC}=\mathrm{HCTS} \& \mathrm{sp}=-$

$1 \& \mathrm{pq}=$ costs + of + death + row + pris $\&$ sc $=0$ -

$23 \& \mathrm{qs}=\mathrm{n} \& \mathrm{sk}=\& \mathrm{cvid}=\mathrm{d} 5 \mathrm{cf5b} 07 \mathrm{fd} 4 \mathrm{~d} 462 \mathrm{cb} 0 \mathrm{e} 6762126 \mathrm{a} 88 \mathrm{~b} 6 \mathrm{e} \&$ first $=8 \& \mathrm{FORM}=\mathrm{PERE}$

83 retrieved from https://enddeathpenaltyde.org/why-repeal/cost/

84 retrieved from https://www.themarshallproject.org/2014/12/17/six-reasons-the-death-penalty-isbecoming-more-expensive

85 retrieved from http://www.ncsl.org/research/civil-and-criminal-justice/death-penalty.aspx

86 retrieved from https://www.prisonpolicy.org/scans/crime_report.pdf

87 retrieved from Baskas, R. S. (2015) as cited in https://files.eric.ed.gov/fulltext/ED560264.pdf

88. retrieved from https://all4ed.org/press/crime-rates-linked-to-educational-attainment-newalliance-report-finds/

89 retrieved from

https://scholarlycommons.susqu.edu/cgi/viewcontent.cgi? article=1026\&amp=\&context=supr\&amp= \&sei-

redir $=1 \&$ referer $=$ https $\% 253 \mathrm{~A} \% 252 \mathrm{~F} \% 252 \mathrm{Fwww}$.bing.com $\% 252 \mathrm{Fsearch} \% 253 \mathrm{Fq} \% 253 \mathrm{Dcosts} \% 252$

Bof\%252Bdeath\%252Brow\%252Bprisoners\%2526mkt\%253Den-

us\%2526httpsmsn\%253D1\%2526refig\%253Dd5cf5b07fd4d462cb0e6762126a88b6e\%2526PC\%253

DHCTS\%2526sp\%253D-

$1 \% 2526 \mathrm{pq} \% 253 \mathrm{Dcosts} \% 252 \mathrm{Bof} \% 252 \mathrm{Bdeath} \% 252 \mathrm{Brow} \% 252 \mathrm{Bpris} \% 2526 \mathrm{sc} \% 253 \mathrm{D} 0$ -

23\%2526qs\%253Dn\%2526sk\%253D\%2526cvid\%253Dd5cf5b07fd4d462cb0e6762126a88b6e\%252

6first $\% 253$ D8\%2526FORM\%253DPERE\#search=\%22costs\%20death\%20row\%20prisoners\%22

90 retrieved from https://www.childstats.gov/AMERICASCHILDREN/tables/pop1.asp

91 retrieved from

https://www.bing.com/search?q=\%22While\%20the\%20amounts $\% 20$ other $\% 20$ studies $\% 20$ have $\% 20$ b roken $\% 20$ down $\% 20$ the $\% 20$ costs $\% 20$ of $\% 20$ incarceration $\% 20$ by $\% 20$ state $\% 2$ C $\% 20$ type $\% 20$ of $\% 20$ in 
carceration. $\% 20$ The $\% 20$ average $\% 20$ cost $\% 20$ of $\% 20$ incarcerating $\% 20$ an $\% 20$ American $\% 20$ prisoner $\% 20$ varies $\% 20$ from $\% 20$ state $\% 20$ to $\% 20$ state. $\% 20$ Some $\% 20$ states $\% 2$ C $\% 201$ like $\% 20$ Indiana $\% 20$ have $\% 20$ managed $\% 20$ to $\% 20 \mathrm{keep} \% 20$ prices $\% 201$ ow $\% 20$ at $\% 20$ around $\% 20 \% 2414 \% 2 \mathrm{C} 000 \% 20$ per $\% 20 \mathrm{in}$ mate. $\% 20$ While $\% 20$ states $\% 20$ like $\% 20$ New $\% 20$ York $\% 20$ pay $\% 20$ around $\% 20 \% 2460 \% 2$ C000\%20to \%20keep $\% 20$ its $\% 20$ citizens $\% 20$ behind $\% 20$ bars. $\% 20$ The $\% 20$ costs $\% 20$ of $\% 20$ running\%20the\%20A merican $\% 20$ prison $\% 20$ system $\% 20$ is $\% 20$ expensive $\% 20$ and $\% 20$ has $\% 20$ become $\% 20$ increasingly $\% 20$ so $\% 20$ despite $\% 20$ public $\% 20$ opposition. \&qs $=$ n\& form $=$ QBRE $\&$ sp $=-1 \& p q=\% 22 \& s c=0$ $1 \&$ sk=\&cvid=EA1B91390BC5414EA38F58FB3F916182

92 retrieved from https://www.justice.gov/agencies/list

93. retrieved from

https://www.bing.com/search? $\mathrm{q}=\mathrm{C}+\mathrm{Cost}+$ per+prisoner+has + doubled + since $+2005 .+$ The + price + for $+\mathrm{e}$ ach + inmate + has + doubled + since $+2005 \% 2 \mathrm{C}+$ even + as + court + orders + related + to + overcrowding + have + reduced + the + population + by + about + one-quarter. \& form $=$ EDGSPH\&mkt $=$ enus\&httpsmsn $=1 \&$ refig $=$ cb2b2b7dfbf64c13ba2870043d0d08be\&PC $=$ HCTS\&sp $=-$

$1 \& \mathrm{pq}=\mathrm{c}+$ cost + per + prisoner + has + doubled + since $+2005 .+$ the + price + for + each + inmate + has + doubled + since $+2005 \% 2 \mathrm{C}+$ even + as + court + orders + related + to + overcrowding + have + reduced + the + population + by + about + one-quarter. $\& s c=0-188 \& q s=n \& s k=\& c v i d=c b 2 b 2 b 7 \mathrm{dfbf} 64 \mathrm{c} 13 \mathrm{ba} 2870043 \mathrm{~d} 0 \mathrm{~d} 08 \mathrm{be}$

95 retrieved from https://deathpenaltyinfo.org/testimony-richard-c-dieter-esq-executive-directordeath-penalty-information-center-illinois-house-re

96 retrieved from

https://www2.ed.gov/rschstat/eval/other/expenditures-corrections-education/brief.pdf

97 retrieved from https://www.forbes.com/sites/kellyphillipserb/2014/05/01/considering-the-deathpenalty-your-tax-dollars-at-work/\#2242d6d664b3

98 retrieved from https://deathpenaltyinfo.org/costs-death-penalty

99 retrieved from https://www.themarshallproject.org/2014/12/17/six-reasons-the...

100 retrieved from tcadp.org/wp...makes-the-Texas-death-penalty-so-expensive-print.pdf

101 retrieved from https://www.usatoday.com/story/news/politics/2018/12/20/criminal-justicereform-bill-passes-congress-goes-president-trump/2373992002/

Berry, D. B., \& Collins, E. USA TODAY Published 2:03 p.m. ET Dec. 20, 2018 | Updated 5:38 p.m. ET Dec. 20, 2018

Kelly, S. (2016). The US spends a troubling amount of money on prisons compared to schools. Reuters. Jul. 7, 2016, 7:49 PM (Editing by Andrew Hay)

McCormack, S. (2016). Federal Prison Population Soars By 790 Percent Since 1980: Report: Increases in Spending on Corrections Far Outpace Education. Press Office, (202) 4011576,press@ed.gov 